\title{
Functional Roles of FGF Signaling in Early Development of Vertebrate Embryos
}

\author{
Vijay Kumar ${ }^{1}{ }^{\mathbb{D}}$, Ravi Shankar Goutam ${ }^{1}$, Soochul Park ${ }^{2}$, Unjoo Lee ${ }^{3}$ and Jaebong Kim ${ }^{1, *}$ \\ 1 Department of Biochemistry, Institute of Cell Differentiation and Aging, College of Medicine, \\ Hallym University, Chuncheon 24252, Korea; vijay10187@gmail.com (V.K.); \\ ravi2005gautam@gmail.com (R.S.G.) \\ 2 Department of Biological Sciences, Sookmyung Women's University, Seoul 04310, Korea; \\ scpark@sookmyung.ac.kr \\ 3 Department of Electrical Engineering, Hallym University, Chuncheon 24252, Korea; ejlee@hallym.ac.kr \\ * Correspondence: jbkim@hallym.ac.kr
}

Citation: Kumar, V.; Goutam, R.S.; Park, S.; Lee, U.; Kim, J. Functional Roles of FGF Signaling in Early Development of Vertebrate Embryos. Cells 2021, 10, 2148. https://doi.org/ $10.3390 /$ cells 10082148

Academic Editor: Stijn De Langhe

Received: 1 July 2021

Accepted: 18 August 2021

Published: 20 August 2021

Publisher's Note: MDPI stays neutral with regard to jurisdictional claims in published maps and institutional affiliations.

Copyright: () 2021 by the authors. Licensee MDPI, Basel, Switzerland. This article is an open access article distributed under the terms and conditions of the Creative Commons Attribution (CC BY) license (https:// creativecommons.org/licenses/by/ $4.0 /)$.

\begin{abstract}
Fibroblast growth factors (FGFs) comprise a large family of growth factors, regulating diverse biological processes including cell proliferation, migration, and differentiation. Each FGF binds to a set of FGF receptors to initiate certain intracellular signaling molecules. Accumulated evidence suggests that in early development and adult state of vertebrates, FGFs also play exclusive and context dependent roles. Although FGFs have been the focus of research for therapeutic approaches in cancer, cardiovascular disease, and metabolic syndrome, in this review, we mainly focused on their role in germ layer specification and axis patterning during early vertebrate embryogenesis. We discussed the functional roles of FGFs and their interacting partners as part of the gene regulatory network for germ layer specification, dorsal-ventral (DV), and anterior-posterior (AP) patterning. Finally, we briefly reviewed the regulatory molecules and pharmacological agents discovered that may allow modulation of FGF signaling in research.
\end{abstract}

Keywords: FGF; FGFR; embryonic development; germ layer formation; transcription regulation; embryonic patterning

\section{Introduction}

Early embryogenesis in vertebrate embryos involves the irreversible developmental process. As the ovum receives the male haploid genome from a sperm to become a diploid cell, the process of fertilization is started with the fertilized ovum then being referred to as a zygote. The zygote goes through several key developmental stages including mid-blastula transition (MBT), gastrulation (germ layer formation), and neurula, for establishing the overall body axis and generating the anterior CNS and posterior PNS (Figure 1). These are tightly controlled spatiotemporal events led by several signaling pathways and occur in conjunction with maternal or zygotic morphogen gradients throughout the embryos. FGF signaling is known to play an essential role during embryonic development [1-3], and in this review, our discussion was focused on involvement of FGF signaling in early embryogenesis. The first discovered FGF ligand, FGF2 (also known as basic FGF/bFGF), was purified from brain tissue in 1975 and was defined for its stimulatory activity in fibroblasts [4]. Since then, a total of 22 FGF members have been identified in humans and similar numbers in vertebrates. Except for the intracellular FGF11 subfamily, these interact with particular FGF receptors (FGFRs) to activate intracellular effector proteins. FGF/FGFR signaling regulates a plethora of cellular processes mediated by activation/modification of cytosolic effectors and followed by transcriptional regulation of target genes. Dysregulation of FGF signaling has been reported to promote several human diseases and disorders, and their severity can vary based on active ligands/receptors and tissues involved [5]. Several lines of evidence also indicate a crucial role for FGF signaling in early embryogenesis 
for germ layer formation [1,2] and organogenesis [6]. During primordial germ layer specification, FGFs modulate fate determination as autocrine and paracrine signaling agents. Alterations in tightly regulated FGF expression patterns, as with altered FGFR splicing or mutation and changes in spatiotemporal FGF-FGFR interactions, may result in flawed and defective development for multiple congenital diseases and the onset of various cancer types $[5,7,8]$. In FGF/FGFR genes, genetic mutations that lead to several congenital diseases have been described reviewed elsewhere [9]. In this review, we summarized the information and our understanding of the functional role(s) of FGFs in early embryonic germ layer specification and axis formation during embryogenesis.

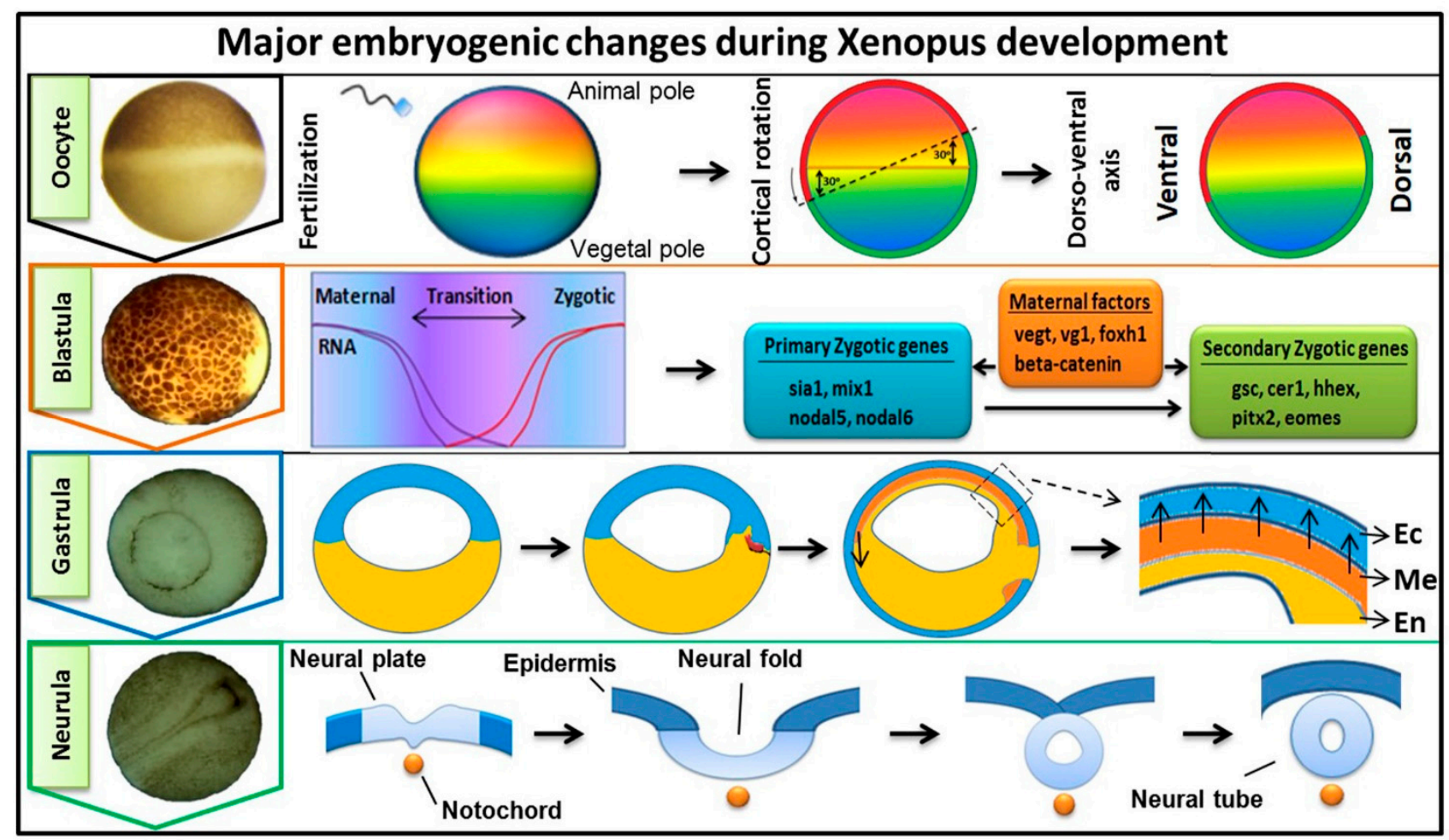

Figure 1. Key developmental stages and major events during oocyte, blastula, gastrula, and neurula. Oocyte: sperm entry establishes the DV (dorsal-ventral) axis. Blastula: mid-blastula transition (MBT) whereby expression of zygotic genes begin with maternal factors inducing primary zygotic and secondary zygotic genes. Gastrula: a cluster of dorsal mesodermal cells start their migration and form the three primary germ layers (Ec (ectoderm), Me (mesoderm, arrow head indicates the secretion of extracellular proteins such as Chordin), and En (endoderm)). Neurula: formation of the neural tube and AP axis establishment.

\section{FGF and FGFR Families and Signal Transduction}

\subsection{FGF Ligands}

The FGFs are a large family of growth factors consisting of 22 members in humans and mice, and 19 members identified in Xenopus (Table 1). In this family, there are seven subfamilies described in vertebrates, namely FGF1, FGF4, FGF7, FGF8, FGF9, FGF11, and FGF19 (reviewed [10,11]). Subfamily members have high similarity in their amino acids sequences. Except for the intracellular FGF11 subfamily, extracellular secretion of a given FGF is required for its signaling and function. Based on their secretion profile, FGF members can also be placed into two groups. The first are those whose secretion takes place through a classic endoplasmic reticulum-Golgi secretion pathway in the cells as these FGFs contain $N$-terminal hydrophobic peptides and they include FGF3, 4, 5, 6, 7, 8, 10, 17, 18, 19, 21, and 23 [10]. The second group of FGFs are those that do not contain $N$-terminal hydrophobic peptides and are endoplasmic reticulum-Golgi-independent for their secretion. These include FGF1, 2, 9, 16, and 20 [10-12]. As an exception, FGF22 remains attached to the cell 
surface by its $N$-terminal signal peptide rather than being secreted (reviewed [10]). All members of FGF11 subfamily (Table 1) are known as non-secretory FGFs and are strictly intracellular proteins. Even though these FGFs share structural homologies with other secreted FGFs, they do not share any functional similarities $[13,14]$. As intracellular entities, FGF11 subfamily members have been documented as being components of certain protein kinase-mediated signaling pathways and they also interact with membrane channels to regulate cell fate $[15,16]$.

\subsection{FGF Receptors}

FGFs interact with specific FGF receptors to initiate intracellular signaling and there are four cell membrane tyrosine kinase FGF receptors, FGFR1, 2, 3 and 4, which are members of the larger receptor tyrosine kinase (RTK) group $[17,18]$. Each FGFR is a singlepass transmembrane (TM) protein that includes an $N$-terminal extracellular ligand FGF binding domain and a $C$-terminal intracellular tyrosine kinase domain. The extracellular domain contains 3 immunoglobulin-like subdomains (D1, D2, and D3 domains) [19]. There is an also an acidic box between D1 and D2 domains. The D2 and D3 domains facilitate FGF binding [19]. Heparan sulfate (HS) is a coreceptor for FGF binding to an FGFR, and it is essential for FGF binding and signaling. HS is one of the abundant polysaccharides found in the extracellular matrix of mammalian cells [20], and it interacts with the cationic patch found in both FGF and D2 subdomain of FGFR [20]. Ligand binding induces a conformational change in FGFR, leading to its dimerization and activation of the its intracellular kinase [21]. For FGFR1, FGFR2, and FGFR3, two standard isoforms (b-and c-isoforms) are generated by splicing [22]. The splicing variants have altered ligand affinity for various FGFs, except for FGF1, acknowledged as a universal ligand and being able to interact with both FGFR isoforms $[17,20]$.

\subsection{An Overview of FGFR Signaling Pathways}

In this section, we briefly summarized the activation modes of FGFR associated cytosolic effectors and linked components that act as intermediates. Several partner receptor proteins may be associated with the cytosolic domain of an FGFR, such as cell adhesion molecules (CAMs) and G-protein coupled receptors (GPRCs) [23]. Signal-induced activation of FGFR typically activates multiple cytosolic signaling pathways. An FGFR is mainly associated with its intracellular signaling intermediates, including phospholipase C (PLC $\gamma$ ), FRS1, FRS2/FRS2 $\alpha$, and FRS3/FRS2 $\beta$ (reviewed [24]). FRS2 recruits the adaptor GRB2 (growth factor receptor-bound 2) [25], and once GRB2 is bound to the functional domain of the FRS2, it can interact with either SOS or GAB1 and form a complex [26]. Upon FGF ligand binding to FGFR and heparan sulfate, multiple cytosolic events occur; these are mostly activational phosphorylations. Once the FGFR complex is activated, GRB2/SOS exchanges the GDP to GTP for Ras; GTP-Ras in turn activates and stimulates Raf (also known as MAPK kinase kinase) as part of the Ras/MAPK pathway (for a detailed mechanism, refer to reviews [27-30]). Similarly, GRB2 switches on PI3K/Akt signaling cascade, as activation of PLC $\gamma /$ PKC and JAK/STAT pathways are also directly linked to FGFR activation [27-30]. These pathways generate the signals leading to targeted transcription factors regulating transcription of their target genes. 
Table 1. Known FGFs and FGFRs in human, mice, and Xenopus.

\begin{tabular}{|c|c|c|c|c|c|c|}
\hline \multirow[b]{2}{*}{ Subfamily } & \multicolumn{2}{|l|}{ Human } & \multicolumn{2}{|c|}{ Mouse } & \multicolumn{2}{|l|}{ Xenopus } \\
\hline & $\begin{array}{c}\text { Members } \\
\text { (Other Name) }\end{array}$ & Ref. & $\begin{array}{c}\text { Members } \\
\text { (Other Name) }\end{array}$ & Ref. & $\begin{array}{c}\text { Members } \\
\text { (Other Name) }\end{array}$ & Ref. \\
\hline \multirow{2}{*}{ FGF1 } & FGF1 (aFGF) & [31] & FGF1 (FGFa) & [32] & xFGF1 & [33] \\
\hline & FGF2 (bFGF/FGF- $\beta$ ) & [4] & FGF2 & [34] & xFGF2 (bFGF) & [35] \\
\hline \multirow{3}{*}{ FGF4 } & FGF4 (eFGF) & [36] & FGF4 (KFGF) & [37] & $\begin{array}{l}\text { xFGF4 (eFGF, fgf4-a, } \\
\text { fgf4-b) }\end{array}$ & [38] \\
\hline & FGF5 & [39] & FGF5 & [40] & xFGF5 & {$[33,41]$} \\
\hline & FGF6 (HST2, HSTF2) & [42] & FGF6 (HSTF2) & [43] & xFGF6 & {$[33,41]$} \\
\hline \multirow{4}{*}{ FGF7 } & FGF3 & [44] & FGF3 (Int-2) & [45] & xFGF3 (INT-2, FGF3A) & [46] \\
\hline & FGF7 (KGF) & [47] & FGF7 (KGF) & [48] & * & \\
\hline & FGF10 & [49] & FGF10 & [50] & xFGF10 & [51] \\
\hline & FGF22 (UNQ2500/PRO5800) & [52] & FGF22 & [52] & xFGF22 & [41] \\
\hline \multirow{3}{*}{ FGF8 } & FGF8 (AIGF) & [53] & FGF8 (AIGF) & [54] & xFGF8 (FGF8a, FGF8b) & [55] \\
\hline & FGF17 (UNQ161/PRO187) & [56] & FGF17 & [56] & $*$ & \\
\hline & FGF18 (UNQ420/PRO856) & [57] & FGF18 & [57] & * & \\
\hline \multirow{3}{*}{ FGF9 } & FGF9 & [58] & FGF9 & [59] & xFGF9 (GAF, HBGF9) & [60] \\
\hline & FGF16 & [61] & FGF16 & [62] & xFGF16 & [41] \\
\hline & FGF20 & [63] & FGF20 & [64] & xFGF20 & [65] \\
\hline \multirow{4}{*}{ FGF11 } & FGF11 (FHF3) & [66] & FGF11 (FHF3) & [66] & xFGF11 & [41] \\
\hline & FGF12 (FGF12B, FHF1) & [66] & FGF12 (FHF1) & [67] & xFGF12 & [68] \\
\hline & FGF13 (FHF2) & [69] & FGF13 (FHF2) & [67] & xFGF13 & [70] \\
\hline & FGF14 (FHF4) & [71] & FGF14 (FHF4) & [72] & xFGF14 (FHF4) & [33] \\
\hline \multirow{9}{*}{ FGF19 } & * & & FGF15 & [73] & $*$ & \\
\hline & FGF19 (UNQ334/PRO533) & [74] & $*$ & & xFGF19 & [41] \\
\hline & FGF21 (UNQ3115/PRO10196) & [75] & FGF21 & [75] & * & \\
\hline & $\begin{array}{c}\text { FGF23 (HYPF, } \\
\text { UNQ3027/PRO9828) }\end{array}$ & [76] & FGF23 & [76] & $\begin{array}{l}\text { xFGF23 (fgf23.1, } \\
\text { FGF23.2) }\end{array}$ & [41] \\
\hline & \multicolumn{6}{|c|}{ FGF receptor family } \\
\hline & FGFR1 & [31] & FGFR1 & [77] & xFGFR1 & [78] \\
\hline & FGFR2 & [79] & FGFR2 & [80] & xFGFR2 & [81] \\
\hline & FGFR3 & [82] & FGFR3 & [83] & xFGFR3 & [84] \\
\hline & FGFR4 & [85] & FGFR4 & [86] & xFGFR4 & [87] \\
\hline
\end{tabular}

Asterisk $\left(^{*}\right)$ represent unidentified.

\section{FGF Signaling in Embryonic Germ Layer Formation}

Cellular diversification is an essential process in generating a complex, multicellular organism. This process begins with gastrulation as the three germ layers of endoderm, mesoderm, and ectoderm are specified. For an amphibian embryo, the first embryonic germ to specify is the endoderm from the vegetal pole. The formation of mesoderm, the second germ layer, is the result of active mesoderm inducing signals, originating from the vegetal region or the prospective endoderm, which triggers the mesoderm specification. During the mesoderm specification, generally two distinct signaling centers, namely the ventral and dorsal signaling centers, are established in the marginal region; these are based on presence and activation of maternal or zygotic factors at ventral and dorsal half of the embryo (Figure 2A). Once the ventral and dorsal signaling centers are established, they both collectively drive further germ layer specification. The dorsal centers (also called the dorsal mesoderm, dorsal organizer, and organizer) produce dorsal mesoderm and promote neuroectoderm formation by inhibiting ventral signaling. On the opposite end, the 
ventral center provides the ventral mesoderm and the ectoderm (for epidermis formation) (Figure 2A). In this section, we try to summarize primordial germ layer formation and the active role of FGF signaling in this process.

\section{A, fate map of primordial germ layer and formation}
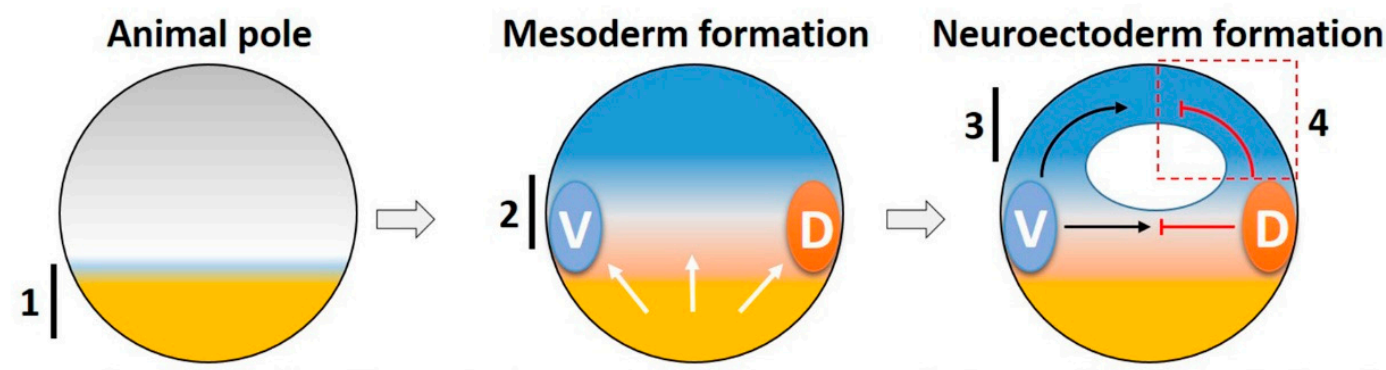

Vegetal pole (1; endoderm, 2; mesoderm, 3; ectoderm, 4; neuroectoderm) (V; ventral, D; dorsal)

\section{B, embryonic axis formation}
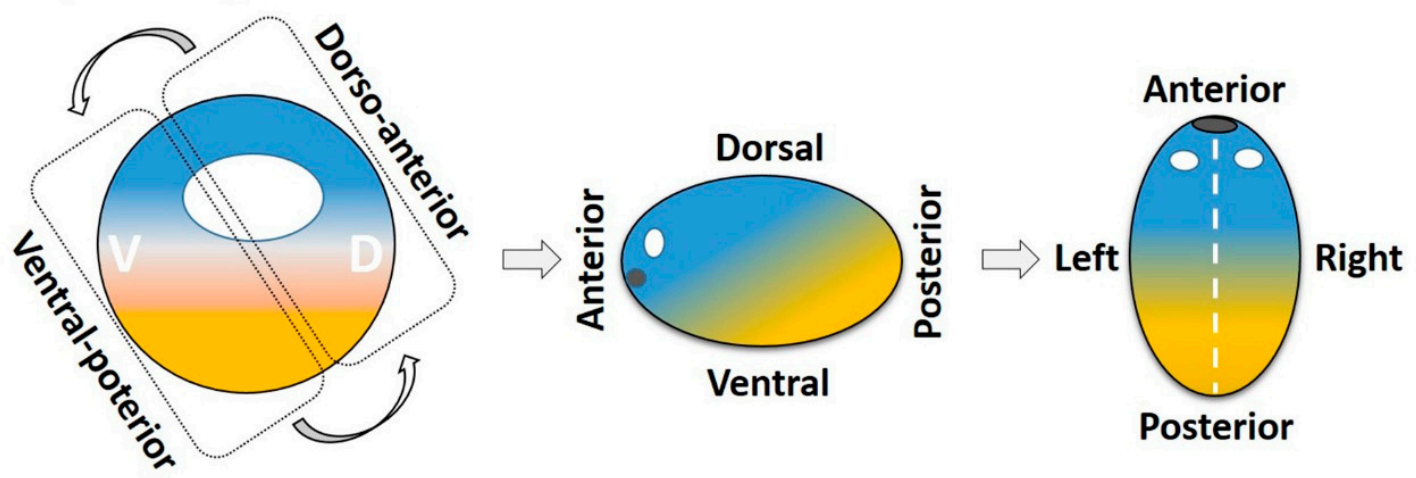

Figure 2. The fate map and key steps in overall embryonic germ layer and axes formation. (A) Vegetal pole (endoderm) contains higher amounts of maternal factors that generate the mesoderm inducing signals (white arrows). These mesoderm inducing signals establish the ventral (V) and dorsal (D) signaling centers. Finally, dorsal signals (BMP antagonists) antagonize the ventral and allow the neuroectoderm formation (red dotted box), as ventral signaling commences the ectoderm (epidermis) specification. (B) Sequential steps in embryonic axes formation: Dorsal and ventral halves extend to give the anterior and posterior axes, respectively. The left-right (LR) axis establishes the neurula stage embryos by a symmetry breaking signal. The LR axis is generally described by positioning of the visceral organs along the midline (white dotted line).

\subsection{Role of FGF Signaling in Endoderm Formation}

In amphibian embryo, the vegetal half (vegetal pole) contains several important maternal factors (also called as vegetal factors) that might govern early primordial germ layer formation. To date, several transcription factors primarily located in the vegetal region have demonstrated consistent inductive activity for germ layer differentiation. One instance is Vegt (also known as Xombi and Brat), which is a maternal T-box transcription factor as depleted vegt abolished endoderm formation and overall germ layer patterning [88]. Similarly, blocking of Vg1, one of the maternal (TGF $\beta$ family) vegetal factors, severely curtailed endoderm and mesoderm (mostly for dorsal organizer) development in Xenopus embryos [89]. These results indicate that Vegt and Vg1 are important, necessary factors for endoderm formation. Depleted vegt dramatically reduced the expression of $f g f 3, f g f 4$, $f g f 8, X n r 1, X n r 2$, and Xnr4; however, expression of $b m p 4$ and $b m p 7$ remained unaffected or were increased [90]. FGF signaling then showed an inhibitory effect on endodermal differentiation and blocking FGF signaling with DNFR in ectodermal explants induced en- 
dodermal specific genes endodermin (edd) and mixer expression [91]. Recently, Dusp1 (dual specificity phosphatase 1, a FGF signaling modulator) reported to increase the expression of edd, mixer, and sox17 $\beta$ (endodermal marker) in a activin/smad2-dependent manner [92]. The one possible explanation of this observation may be additional expression of dusp1 with smad2 might inhibit the FGF signaling and indirectly induces smad2 mediated endodermal differentiation. Similarly, morpholino based knockdown of Dusp4 (a MAP kinase inhibitor) abolishes the expression of sox17 and endodermal defects [93]. Similarly, DNFR injection in the vegetal region led to enlarged endodermal tissue in whole Xenopus embryos (Figure 3B) [91]. There have been supporting reports on zebrafish embryos, where FGF/ERK signaling leads to inhibitory phosphorylation of Sox32 (an endodermal specifier), and thus not being able to induce Sox17 [94]. These set of experiments implied that FGF signaling may be required for limiting endodermal genes expression in a negative feedback loop, and that FGF levels may need to be below a certain threshold for endoderm to proceed.

The role of FGF signaling, however, is not always endoderm inhibitory, at least in certain systems. From stem cell research, FGFs cooperate with activin signaling in promoting endodermal differentiation as the down-regulation of FGF signaling by SU5402 (an FGF inhibitor) abolished activin-A induced definitive endoderm formation in human embryonic stem cells (hESCs) [95]. The activin-A treatment induces definitive endoderm expression additively when FGF2 is additionally supplied to the culture media. In this system, activin-mediated definitive endoderm induction required FGF signaling, but the converse was also true as FGF2 failed to induce definitive endoderm under activin depleted conditions [95]. These effects indicate that definitive endoderm differentiation might be a combined effect of activin and FGF signaling in hESCs. Several other maternal or zygotic transcription factors have also been reported to induce endodermal fate, for example Otx1, Sox7, and Sox17 (reviewed in [96]). These research findings point to endoderm fate specification being the result of coordinated signaling from distinct pathways, but the role and conditions of FGF signaling in whether being antagonistic or additive/synergetic in endoderm formation is poorly understood and requires further analysis.

\subsection{FGF in Mesoderm Induction}

In 1969, an inductive role for endoderm in inducing mesoderm formation was demonstrated. In this experiment, the section from the animal half (animal explant or animal caps) and the section from vegetal half were conjugated and cultured [97]. Surprisingly, an animal cap keeps ectodermal identity autonomously; in the conjugation condition, it converts to a mesodermal tissue, while a vegetal explant keeps its original identity and remains endoderm (Figure 3) [97]. Later on, bFGF (FGF2) or eFGF (FGF4) were implicated in inducing mesoderm in animal cap explants of Xenopus embryos, mimicking vegetal explant activity [91,98]. A similar finding was demonstrated in rabbits [99] and mice [100], where FGF2 sufficiently induced mesoderm differentiation. In 1991, when Amaya et al. injected a dominant-negative mutant of the FGF receptor (DNFR/XFD) into Xenopus embryos, ectopic expression of DNFR sufficiently blocked the wild-type FGFR mediated signaling [101]. The DNFR injected embryos completely failed to produce mesodermal tissue [101]. In mice, targeted point mutation of FGFR1 led to embryos exhibiting several subtypes of mesodermal defects [102]. Since then several independent studies have provided crucial evidence indicating FGF signaling as an important instructive factor in mesoderm differentiation of vertebrates [101-105].

The active molecules with mesoderm inductive activity from the vegetal hemisphere include members of Xenopus nodal-related factors (Xnr1, 2, 4, 5, and 6) and TGF $\beta$ family (activin $\beta B$ ), now known as endogenous mesoderm inducing factors in various animal models, including Xenopus, zebrafish, and mouse [106-109] and the signaling pathways utilized by these signals are often due to activin ligands [106-109]. This mesoderm inducing effect by activin treatment in metazoan embryogenesis is now widely accepted. The ectopic expression of activin/Nodal downstream intracellular effectors Smad2/3 activate 
xbra, chordin (chrd), noggin (nog), and goosecoid (gsc) expression [110]. Activin-mediated mesoderm induction critically depends on FGF signaling, as demonstrated when DNFR led to complete loss of mesodermal genes expression due to activin [111]. In comparison, ectopic expression of Smad2 significantly elevates expression of various FGFs and FGFRs including $f g f 3, f_{g} f 8, f_{g} f 20, f_{g} f r 1$, and $f g f r 2$ [92]. Supporting the role of FGFR signaling in mesoderm induction is also observed with the expression profile of several FGF ligands in early mesoderm of vertebrate embryos. $F g f 3$ expression is primarily in the ring around blastopore lip (mesoderm) of Xenopus gastrula, which then resolves into neural or brain tissues at a later stage of development [112]. Similarly, $f g f 4, f g f 8$, and $f g f 20$ are largely expressed in early mesoderm or late mesodermal lineages [113-116]. However, integration of FGF and activin/nodal signaling in mesoderm specification is a potential subject for a future investigation.

Brachyury (Bra/Xbra) is a T-box transcription factor and signature mesodermal (also known as a pan-mesodermal marker) factor, and is actively involved in gene regulation process required for mesoderm induction and differentiation $[117,118]$. Similarly, Eomesodermin (Eomes) is another T-box transcription factor, an important mesodermal factor crucial for mesoderm induction and differentiation [119]. Both proteins are necessary for mesoderm induction; however, Xbra is also involved in expression of ventral/posterior specific genes (e.g., ventx1.1 and $x$ hox3) $[117,120-122]$. Xbra is indispensable for mesoderm formation and maintenance since knockdown of Xbra converts its mesodermalizing character to a neuralizing one [123,124]. Eomes has been reported to induce dorsal/anterior mesodermal (gsc, chrd, and nog) genes in Xenopus embryos [119]. Xbra early expression was reported to depend on FGF signaling as embryos treated with SU5402, showed no $x b r a$ expression [114]. In turn, FGF2 and FGF4 have been reported to induce $x b r a$ transcription in animal explants of Xenopus embryos, wherein Xbra makes an autocatalytic regulatory loop to maintain the Fgf4 expression [123,125]. Xbra can maintain the expression $f g f 4$, but its activation is most likely thought to depend on Nodal signaling; this is similar to $f g f 8$ activation largely depending on nodal/activin signaling [114]. FGF8, have two alternative splice variants (protein isoforms), namely FGF8a and FGF8b, and these show different inductive features. FGF8a has been reported to have mostly neural inducing activity with little mesoderm inducing capability, whereas FGF8b is important for mesoderm induction and differentiation [55].

FGF signaling has an indispensable role in mesoderm induction and specification, but the detailed molecular mechanisms by which different FGF ligands regulate a different subset of mesodermal markers is not fully understood. Based on their spatiotemporal expression patterns, these markers may be divided as dorsal, ventral, and pan-mesodermal markers. In dorsal mesoderm of Xenopus gastrula, chrd, nog, gsc, and siamois (sia) are highly expressed in dorsal mesoderm [126], in which gsc expression is sustained under FGF inhibitory conditions [127]. However, chrd and nog (from the organizer) have been reported to be both sensitive and insensitive to FGF signaling, thus complicating the interpretation of their underlying mechanism $[127,128]$. As Nodal/activin signaling also plays an upstream role for various mesodermal genes $[103,107,109,110]$, the exclusive involvement of FGF signaling at a transcriptional level for these set of genes is not fully understood.

With the early ventral mesoderm, which later leads to development of posterior tissues, several pieces of evidence indicate that FGF signaling plays an upstream role to the RAR (retinoic acid receptor) [129]. In particular, RAR $\alpha 2$ has been reported to cooperate with FGF signaling and also required for normal expression of FGF8, FGFR1, and FGFR4 [129]. RAR $\alpha 2$ and FGFs are collectively required for $x c a d 3$ and hoxb9 (posteriorizing factors) expression and normal axis development in Xenopus [129]. Cdx (caudal type homeobox) transcription family are also known to be transcriptionally activated by FGF signaling and be necessary for proper dorsoventral axis formation [130-132]. A further crosstalk of various pathways involves FGF dependent Xbra physically interacting with Smad1 to activate the expression of ventx1.1, a ventral mesodermal/ectodermal inducer and a $\mathrm{BMP} /$ Smad1 target transcription factor [120]. 
A

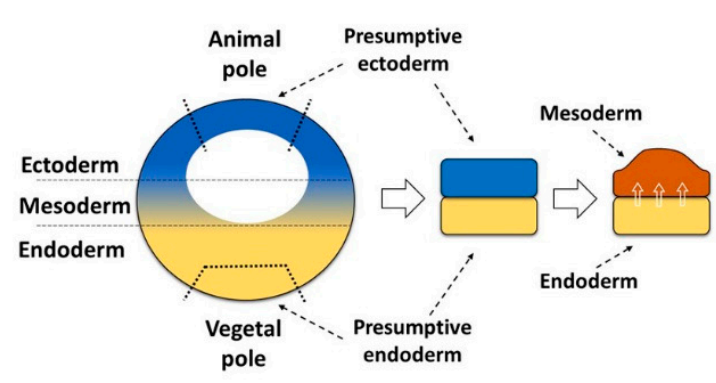

B

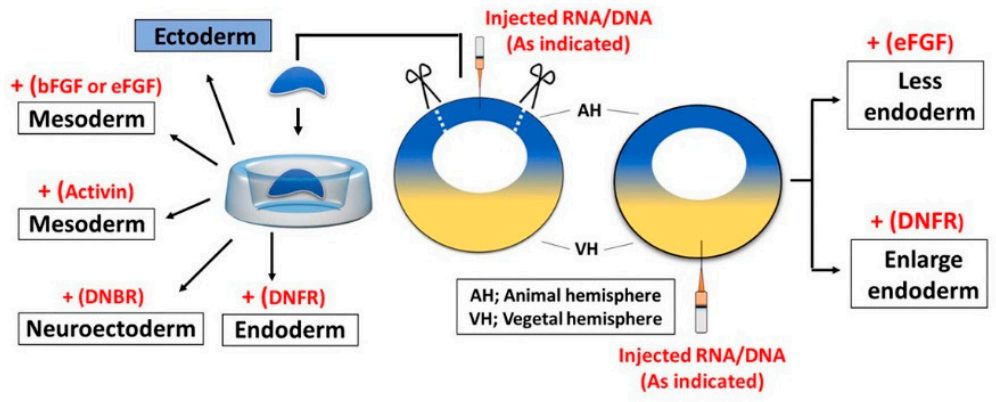

Figure 3. Outline of key experiments in embryonic induction. (A) a conjugation assay for vegetal explant and ectodermal explant. (B) The embryos are injected with RNA/DNA of various genes (indicated in red text) and the dissected explants are then cultured. Upon injection of an inducer, the explants then differentiate into various embryonic germ layers (indicated in boxed text). The majority of experiments are performed with Xenopus embryos.

A spatiotemporal expression of FGF ligands and receptors is seen in Xenopus embryos, suggesting diverse expression patterns among ligands. During gastrulation, $f g f 1$, $f g f 2, f g f 4, f g f 8, f g f 20$, and $f g f 22$ are highly expressed, implying a requirement for mesoderm specification and extension [33]. Several transcription factors have been reported to incorporate FGF signaling in mesoderm specification and embryonic patterning. As an example, mef2d is transcriptionally activated by FGF4 and FGF8 in the marginal region of Xenopus embryos, and from the vegetal region, nodal (Xnr5 and 6) also induces mef2d expression. Once Mef2d protein is made, it can form a positive expression feedback loop with FGF4 and FGF8, leading to the expression of mesodermal genes like $x b r a, c h r d, g s c$, and nog [133]. A similar example of interaction with FGF signaling is for Egr1, which has been reported as a downstream target of FGF signaling and plays an important role in embryonic development. The Egr1 activates the transcription of myod, and represses $x b r a$ transcription [134]. Collectively, the presented evidence suggests that FGF signaling may interact with several other signaling pathways (e.g., activin, nodal, BMP, and RAR) during mesodermal differentiation in a context-dependent manner (for example in the ventral and dorsal mesoderm). However, the details for the different ligands, their receptors, and their mechanistic integration with other key signaling entities remain to be fully elucidated.

\subsection{FGF in Ectoderm Specification}

BMP signaling is essential for ectoderm (epidermal) specification during embryonic development as BMPs activate ectoderm specifier ventx1.1, ventx1.2, and vent $x 2.1$ via the Smad1 pathway to derive epidermal fate $[135,136]$. Previous studies indicate that FGF signaling antagonistically interacts with BMP signaling and inhibits ectoderm differentiation, particularly in the dorsal region of the embryo. The evidence suggests that FGF signaling induces linker region phosphorylation of Smad1 with an inhibitory phosphorylation and reduces C-terminal activational phosphorylation $[120,137,138]$. In Xenopus, blocking BMP signaling also induces $f g f 4$ expression [139]. In zebrafish blastula, FGF restricts the $b m p 2$ and $b m p 7$ expression in the ventral region, promoting the dorsal fate in the BMP inhibited condition [140]. Also in zebrafish, inhibition of FGF signaling extends the BMP activity and generates ventralized embryos [140], again supporting the inhibitory role of FGF in ectoderm formation. FGF signal is inhibitory to BMP/Smad1 in ectoderm specification. However, FGF/Xbra functions synergistically to BMP/Smad1 in ventral mesoderm specification. Interestingly, recent studies suggest that FGF signaling support ventral mesoderm formation. In Xenopus gastrula, FGF downstream target, $x b r a$, a pan mesodermal marker, cooperates with Smad1 to activate ventx1.1 transcription [120], and Xcad2, an FGF downstream target, induces the ventx1.1, ventx1.2, and ventx2.1 expression [130]. These studies demonstrate that the function of FGF in ectoderm and ventral mesoderm specification occurs in two ways: first, as being directly inhibitory to BMP/Smad1 pathway via 
phosphorylation modification of Smad1, and second, being ventral mesoderm promoting with increasing of vent $x 1.1$, vent $x 1.2$, and vent 2.1 (ventral mesoderm markers) levels via Xbra and Xcad2. These findings imply a context-dependent (dorsal vs. ventral region of the embryo) function for FGF on ectoderm formation. The regulation of each modality, however, remains to be further studied.

\subsection{Role of FGF in Neural Induction and Neuroectoderm Formation}

Neuroectoderm formation starts from the superficial ectodermal layer near the organizer [141], in a region known as Henson's node in avian embryos [142], and the embryonic shield in zebrafish [143]. From the organizer, neural inducer activity was first demonstrated for Nog [144] and Chrd [145]. These molecules were first believed to provide direct inductive signals; however, later studies confirmed them as BMP inhibitors in a default model of neurogenesis (reviewed [146,147]), where inhibition of BMP signaling is sufficient to induce neurogenesis. Of the many experiments that supporting this model include the knockdown and deletion of chrd, nog, and Follistatin, abolishing the neural plate formation [148]. Triple knockdown or deletion of BMP antagonists allow BMP and target genes to be robustly expressed, resulting in a complete neural loss. In the converse experiment, however, BMP inhibition was not sufficient for neural fate acquisition. It is concluded that although BMP inhibition is necessary, several inductive signals direct the neural fate in parallel with BMP inhibition [149,150]. This is demonstrated with overexpression of DNFR, dominant-negative FGF receptor, abolishing the neural inducing ability of Chrd and Nog [151,152].

Requirement of FGF signaling in neuroectoderm formation could be considered in two different ways: first, being an instructive signaling, in addition to BMP inhibition, FGF signal itself induces neuroectoderm via activation of neural specific genes. Second, being inhibitory to BMP signaling, to guarantee the neuroectoderm formation, FGF and Map kinase participate in inhibition of Smad1 via linker region phosphorylation. Both ways may function together in neuroectoderm formation. However, the first one is essential and the second one is an additional one since the BMP inhibited condition still requires an FGF input. This implies that intact FGF signaling is necessary as an instructive signal in addition to BMP inhibition for neural fate. Although which FGF member(s) instructs naive ectoderm to neuroectoderm remains to be investigated further, ectopic expression of FGF2 induces the neural genes zic3 expression in animal explant of Xenopus embryos [123]. Another evidence for a role of FGF signaling in this context was with FGF4 signaling shown to activate early neural marker genes zic3 and foxd5a; with BMP inhibition. Zic1 transcription was also increased [139]. BMP signaling inhibited condition also led to increased levels of FGF4, reinforcing the role of FGF signaling in neural induction [139]. This observation raises the possibility of FGF4 involvement in early neural induction and not for the later stages for neural lineages.

More recently, Foxd411.1, an immediate early neural marker, was shown to be induced following inhibition of BMP signaling [153]. Foxd411.1 in naive neuroectoderm can induce expression of $f g f 8 a / b$ in animal explants without $x b r a$ and $f g f 4$ expression [153]. FGF8b contains Smad1 inactivation activity via linker region phosphorylation. FGF8 has been reported to induce the expression of Xsox3 and N-tubulin via FGFR4a signaling [154]. In mice, FGF signaling is also critically required for neural stem cell maintenance and neurogenesis [155]. Similar findings have also been reported in chick embryos [156] again implying a role for FGF signaling in neuroectoderm formation. However, FGF8 may be necessary for further neural development in vertebrates. Indeed, a number of studies have shown a plausible role for FGF8 in later stages, such as midbrain development in chick embryo [157], in retina formation also in chick model [158], and anteroposterior pattering in Xenopus [55]. Together, it still remains largely unknown which FGF member has a role as an endogenous instructive signal to induce neuroectoderm without BMP signal inhibition.

Xenopus embryos provide an easy and powerful tool to investigate the regulatory mechanisms in germ layer specification. In this system, the ventral region (A4 blastomere) 
of 16 or 32 cell-stage embryo fate mapping has this region differentiate into epidermal cells $[127,149]$. However, A4 blastomere cells are capable of neural fate acquisition but they do not achieve neural fate in BMP inhibited conditions [127,149]. These results again demonstrate that BMP inhibition is not sufficient to induce neural fate. FGF signal manipulation in this region was then performed by injection of a low amount of FGF4 along with dominant-negative BMP receptor (DNBR); this was able to induce direct differentiation to neural tissue instead of epidermis $[127,149]$. This study raises a question whether FGF4 is enough to induce neuroectoderm from naïve ectoderm. The basic and embryonic FGF (FGF2 and FGF4) would be sufficient for neuroectoderm formation since FGF/map kinase inhibits BMP/Smad1 signal via phosphorylation of linker region. However, various studies indicate that FGF2/4 alone does not induce neurogenesis in ectodermal explants of Xenopus embryos $[38,123,159,160]$. A direct target transcription factor gene (ventx1.1, PV.1) of BMP/smad1 functions as neural repressor $[136,137]$ whose transcription is also synergistically increased by FGF target gene $x b r a[120]$. Knockdown of ventx1.1 induces neuroectoderm in FGF2 treated ectoderm [123]. The requirement of an FGF signal in addition to the inhibition of BMP for neuroectoderm specification remains to be clarified to resolve the long controversy between the neural induction and default neurogenesis models. In addition, FGF2, FGF4, FGF8, and Foxd411.1 may have different neural target genes but they share remarkable similarity in inhibiting BMP signaling for R-Smad(s) by generating inhibitory phosphorylation of the Smad linker region [55,123,139,149,153,158,160]. Collectively, FGF signaling is important for modulating BMP signaling in neural induction; however, additional details for various FGF ligands and their FGFRs and their individual mode of action are needed for a more complete picture to emerge.

\section{FGF Signaling Integrates with Other Signaling Pathways in a Crosstalk for Embryonic Axis Formation}

For an amphibian embryo, the first embryonic axis is the dorsoventral (DV) axis that is established prior to germ layer formation. The anteroposterior (AP) axis is an extension of the DV axis, in which the dorsal expands to the anterior, and the ventral expands to give the posterior end (Figure 2B). The left-right (LR) axis is last to establish in the amphibian embryo (Figure 2B). The FGF signaling or its crosstalk with other signaling pathways orchestrate the overall embryonic patterning. In this section, we discuss the interplay of FGF with other signaling pathways for axis determination.

\subsection{The DV Axis}

At late blastula and early gastrulation, Xenopus embryos exhibit a dorsoventral (DV) axis that is established prior to mid-blastula transition (MBT) and it involves shifting maternal morphogens or molecular gradients in a process known as cortical rotation (Figure 1). The ventral side is sensitive to BMP signaling and inhibition of BMP signaling expands the dorsal axis. Experiments with downregulation of BMP signaling were performed by application of DNBR [161] or using Smad5-somitabum (an anti-morphic Smad, or dominant negative R-Smad) [139]. These induced dorsal axis or dorsal targeted gene expression. Similarly, an anti-morphic PV.1 (Ventx1.1) triggered higher expression of dorsal marker gsc, chrd, follistatin, and xnot, resulting in formation of the secondary axis [162]. We have previously discussed (Section 3.2, "FGF in mesoderm induction") downstream targets of FGF signaling such as $x b r a$ and $x c a d 2$ known to promote ventral/ectodermal fate via activation of ventx1.1 expression [120,130]. On the other hand, there is evidence supporting FGF signaling in actively promoting the dorsal mesodermal fate. FGF4, FGF8, and FGF20 are highly expressed in the dorsal animal and marginal region of mesoderm while being absent in the ventral vegetal areas $[33,38,115]$. There has also been documentation of ERK (FGF dependent) activation in the dorsal animal region of gastrulation stages [163-165]. There are also indications that FGF-mediated signaling is not a sole regulator of the DV axis as it mutually cooperates with several other signaling modalities such as BMP, activin, nodal, and Wnt/ $\beta$-catenin (reviewed in [166]). 


\subsection{The AP Axis}

The dorsoventral (DV) axis typically expands to continue with anteroposterior (AP) axis development. The dorsal animal region reaches to the anterior and the ventral vegetal region extends to the posterior. The majority of evidence point to FGF signaling as being a posterior inducer. Dissociated cells from an ectodermal explant of Xenopus embryos were shown to adopt an anterior neural fate. However, additional FGF converted their fate to a posterior neural one [167-169], thus pointing to FGF signaling being posteriorinducing. Another set of experiments in Xenopus were performed under reduced levels of FGF activity; these were via FGF signaling block by N17Ras, a dominant-negative Ras mutant, and a truncated FGFR1 (XFD) [170]. Depleted FGF signaling by either N17Ras or XFD led to posterior markers not being expressed [170]. These results support the idea that FGF signaling is actively involved in posterior formation rather than in the anterior. Additional gain of function studies also in Xenopus drew similar conclusions; these were with overexpression of eFGF reported to induce a posteriorized phenotype with enlarging proctodeum and elevated expression level of posterior genes xcad3, hoxB9, and hox $A 7[125,171]$. In these instances of upregulation of posterior genes, the anterior specific factors were suppressed and resulted in small or truncated head formation [125,171].

Within the FGF family, there are also variants of FGFs that may have varying functions in axis development, although they are categorized under the same FGF signaling pathway. For example, FGF8 can generate the highest number of splice variants (FGF8a-h) among FGF family in mice, and these variants are subject to relative expression differences during development (reviewed [172]). FGF8a and FGF8b have been reported to have distinct instructive activity during brain development. In mice, FGF8a strongly induces the midbrain proliferation, wherein FGFb induces hindbrain fate specification, and the misexpression of these variants can revert developmental fate in various vertebrate models [172-175].

Both genes family of caudal homologs and Hox have been reported as the targets of FGF and Wnt signaling during AP elongation in vertebrates [125,171,176-178]. However, a growing body of evidence indicate that FGF signaling is not a solo regulator of AP patterning. Indeed several signaling pathways (such as FGF, RA, and Wnt) actively participate, and coordinate action for overall embryonic axis formation in vertebrate embryos $[125,171,176,177,179-182]$. One example is for MyoD, an important myogenic regulatory factor, which can be activated by efg $f$ and wnt 8 during the Xenopus embryonic development $[183,184]$. Another example is in chick development with RA and FGF signaling cooperating for proper AP formation with RA targeting anterior most Hox genes whereby FGF targeting posterior most hox genes during neural tube development [185]. In mice and chicks, both RA and FGF signaling can also antagonistically interact during posterior development. The FGF signaling is active in the stem zone of undifferentiated cells in the posterior region for competence to become somitic mesoderm or spinal cord. Meanwhile, RA signaling is active in inducing somatic or neural differentiation in the transition zone [186,187]. Both RA and FGF pathways establish morphogen gradients in the anterior to posterior axis with RA concentrations being high at the anterior and FGF being high at the posterior end $[186,187]$.

\subsection{The LR Axis}

The dorsoventral (DV) axis is followed by gastrulation organizing the anteroposterior (AP) axis. The left-right (LR) axis is formed and defined when in vertebrate embryos the anatomy or positions of visceral organs with respect to the midline become apparent. In mice, initiation of embryonic LR patterning may be defined in two crucial steps (reviewed [188]). In the first step, the node releases the asymmetric signals that diffuse toward the left side of lateral plate mesoderm (LPM) during neurula stage embryo. The second step is associated with gene activation in response to these asymmetric signals (reviewed [188]). The first asymmetric signal was reported as Sonic hedgehog (shh) protein in chick embryos [188]. To date, several signaling molecules have been characterized, particularly FGF8 shown to play an important role in LR axis formation across vertebrates [188-191]. 
In chicks, FGF8 induces the right-side determinant wherein shh has been reported with left-side inducer activity. In the right side, FGF8 inhibits the nodal and pitx2 expression and activates $c \operatorname{SnR}$ (chick snail-related gene) expression [190]. Interestingly, in mice, FGF8 and shh exhibit the reverse effects as in the chick as FGF8 is left-side determining while shh promotes right-side determinants [190].

The most critical event in the symmetry-breaking event known to direct LR asymmetry in mammals is nodal flow. The nodal flow generally refers to leftward extracellular fluid movement powered by nodal cilia in the ventral nodes (review [192]). Nodal cilia biogenesis, releasing of VNPs (vesicular nodal parcels), KVs (Kupffer's vesicle), and FGF signaling have all been reported to be actively involved in this process $[2,193,194]$. With regards to the FGF pathway, activation of key genes (foxj1, rfx2, ier2, ift88, and fibp1) responsible for functional nodal cilia are regulated by FGF signaling $[195,196]$, and this plays several plausible roles throughout overall LR axis formation in vertebrates; however, the details of this regulation remain to be fully understood.

\section{Regulation of FGF Signaling}

Several agents have been discovered or experimentally developed that are relatively specific in modulating FGF signaling, and chemically, these include proteins and small molecules. Based on their activities, these modulators may be placed into three groups: The first includes the endogenous activator(s) as those agents having a positive or compensatory activity relative to FGF signaling. Second are the endogenous factors showing inhibitory or negative activity towards FGF signaling. Third includes the group of relatively small molecular-weight compounds, chemically synthesized to act as inhibitors and with use intended mostly for therapeutic or research applications. Prominently known endogenous activators/inhibitors of the FGF pathway were chosen to be briefly discussed.

\subsection{Endogenous Protein Activators}

A positive feedback regulatory mechanism plays an important role in embryonic and post embryonic development in vertebrates. In this process, several modulators may act as co-activators, interacting with a specific domain of an FGF or an FGFR; this interaction can in turn significantly accelerate or amplify FGF signaling. Notably, heparan sulfate proteoglycans (HSPGs) and glypicans are essential extracellular key modulators, which interact with a variety of growth factors including various FGFs and morphogens and their receptors [197]. These interactions can be positive as well as negative on target signaling with fine control being exerted in a spatiotemporal manner. Target signaling may include that for Wnt, Shh, and FGF pathways. Currently, several FGF positive modulators have been identified that include anosmin-1 (An1), Sef1, L1CAM, and FLRT3, and can alter FGF signaling at multiple levels (for more details, we refer the reader to the selected articles [197-200]) (Table 2). Certain small molecules have also been reported to induce FGF signaling. For example, 8-hydroxyquinoline sulfate and pyrithione zinc increases the expression of FGF target genes in zebrafish embryos [199]. However, as these reports provide a thoughtful explanation and clues to the regulatory mechanisms in FGF signaling, detailed mechanisms on the control of FGF signaling in development remain to be fully understood.

\subsection{Endogenous Protein Inhibitors}

A negative feedback mechanism is an essential regulatory strategy for nearly all signaling pathways and this is particularly important during embryonic development. FGF signaling has demonstrated as having an active functional role at multiple steps across embryonic development. To date, a group of endogenous proteins have been identified that show antagonist activity to FGF signals and are generally associated with the negative feedback loop in downregulating FGF signal transduction. One is Sprouty, an intracellular protein that interacts with Drk and Gap1, being components of Ras/MAPK pathway, and blocks their interaction $[197,198]$. Another is Sef, with a similar expression to various $f g f$ 
genes, which is capable of interacting with the cytosolic domain of FGFR and blocking the intracellular effectors interacting with FGFR. An ectopic gain of function of sef, for example, has been shown to reduce phosphorylation of Raf1 and MEK1/2 [199]. Other agents that have been reported are Spred [200], Pyst1/Mkp3 [197], Dusp1 [92], and FRS2 $\alpha / \beta$ [201], all endogenous FGF inhibitors/modulators. All of the above mentioned blockers of FGF signaling may have separate or overlapping targets (see Table 2) and are generally cytosolic effector proteins.

Table 2. Prominent protein modulators of FGF signaling with context and species dependent effects.

\begin{tabular}{ccc}
\hline Modulators & Target & Effect on FGF Signaling \\
\hline Anosmin-1 & Extracellular domain of FGFR & Positive \\
\hline L1CAM & Extracellular domain of FGFR & Positive \\
\hline HSPGs & FGFs or extracellular domain of FGFR & Positive \\
\hline FLRT3 & Intracellular domain of FGFR & Positive \\
\hline Sprouty & Grb/Raf & Negative \\
\hline Sef's/Spred/Pyst1/Dusp's & Modification of several kinases activity like (MAPK, MEK, & Negative \\
\hline
\end{tabular}

\subsection{FGF Modulators in Developmental Biology}

FGF modulators are essential in early embryogenesis as several studies have reported knockdown of various HSPG genes causing defective development in vertebrates and invertebrates (reviewed [202]). The initial reports from a vertebrate model, namely mouse, has the mutation of "lazy mesoderm" (lzme) gene where lzme encodes an enzyme required for glycosaminoglycan biosynthesis) causing defective mesoderm and endoderm migration [203]. Gene expression profiles demonstrated that FGF target genes expression are severely compromised in lzme mutant embryos, whereas the nodal and Wnt3 pathways remained normal [203]. Similar findings have been reported in Xenopus embryos, wherein morpholino-based knockdown of gpc4 (Glypican 4) shows pleiotropic developmental aberrant phenotypes including defected primary axis and forebrain patterning [204]. A detailed discussion of FGF modulators, however, is beyond the focus of current review, and we refer the readers to the related articles [202-207].

\section{Conclusions and Prospects}

Aberrant FGF/FGFR signaling triggers numerous congenital disorders and many cancer types. Evidence obtained from gain-of-function/loss-of-function experiments demonstrates that proper FGF/FGFR function is required for correct embryonic development in vertebrates. The findings we discussed here suggest that various FGF ligands can trigger distinct germ layer specifications exclusively or in coordination with other signaling pathways. Genetic manipulation using recombinant techniques allowed us to investigate the genetic and functional diversity of FGF/FGFR signaling in early embryogenesis and postnatal development of vertebrates. The current understanding of the gene regulatory network (GRN) in embryonic development has made great progress, and we summarized some of the data within our line of investigation particularly for FGF signaling and its crosstalk with other signaling pathways. A number of particular FGFs were characterized that participate in early embryogenesis, and additional investigations for a more complete picture of their role in active GRN are required. The impressive array of additional modern techniques that have now become mainstream will be utilized for this purpose; these include single-cell RNA/DNA sequencing, efficient knock-in/knock-out technology of CRISPR, and characterizing hESCs along with vertebrate embryos. Taken together, this review provides an overview of the findings of the current research on embryonic development and lineage specification concerning FGF signaling in vertebrates. 
Author Contributions: J.K., S.P. and U.L. designed and provided guidance in preparing this manuscript. V.K. researched the literature and wrote this manuscript. R.S.G. helped in drafting of the manuscript. All authors have read and agreed to the published version of the manuscript.

Funding: This article was supported by the Basic Science Research Program through the National Research Foundation of Korea (NRF), which is funded by the Ministry of Education, Science, and Technology of Korea (2016R1D1A1B02008770, 2016M3A9B8914057, 2018M3C7A1056285, and 2021R1A4A1027355).

Institutional Review Board Statement: Not applicable.

Informed Consent Statement: Not applicable.

Data Availability Statement: Not applicable.

Conflicts of Interest: The authors declare no conflict of interest.

\section{References}

1. Bottcher, R.T.; Niehrs, C. Fibroblast growth factor signaling during early vertebrate development. Endocr. Rev. 2005, 26, 63-77. [CrossRef]

2. Dorey, K.; Amaya, E. FGF signalling: Diverse roles during early vertebrate embryogenesis. Development 2010, 137, 3731-3742. [CrossRef]

3. Pownall, M.E.; Isaacs, H.V. FGF signalling in vertebrate development. Colloq. Ser. Dev. Biol. 2010, 1, 1-75. [CrossRef]

4. Florkiewicz, R.Z.; Shibata, F.; Barankiewicz, T.; Baird, A.; Gonzalez, A.M.; Florkiewicz, E.; Shah, N. Basic fibroblast growth factor gene expression. Ann. N. Y. Acad. Sci. 1991, 638, 109-126. [CrossRef]

5. Xie, Y.; Su, N.; Yang, J.; Tan, Q.; Huang, S.; Jin, M.; Ni, Z.; Zhang, B.; Zhang, D.; Luo, F.; et al. FGF/FGFR signaling in health and disease. Signal. Transduct. Target. Ther. 2020, 5, 181. [CrossRef]

6. Kato, S.; Sekine, K. FGF-FGFR signaling in vertebrate organogenesis. Cell Mol. Biol. 1999, 45, 631-638. [PubMed]

7. Katoh, M.; Nakagama, H. FGF receptors: Cancer biology and therapeutics. Med. Res. Rev. 2014, 34, 280-300. [CrossRef] [PubMed]

8. Coumoul, X.; Deng, C.X. Roles of FGF receptors in mammalian development and congenital diseases. Birth Defects Res. C Embryo Today 2003, 69, 286-304. [CrossRef] [PubMed]

9. Moosa, S.; Wollnik, B. Altered FGF signalling in congenital craniofacial and skeletal disorders. Semin. Cell Dev. Biol. 2016, 53, 115-125. [CrossRef]

10. Itoh, N.; Ornitz, D.M. Evolution of the Fgf and Fgfr gene families. Trends Genet. 2004, 20, 563-569. [CrossRef]

11. Ornitz, D.M.; Itoh, N. Fibroblast growth factors. Genome Biol. 2001, 2, REVIEWS3005. [CrossRef] [PubMed]

12. Hui, Q.; Jin, Z.; Li, X.; Liu, C.; Wang, X. FGF Family: From Drug Development to Clinical Application. Int. J. Mol. Sci. 2018, 19, 1875. [CrossRef]

13. Olsen, S.K.; Garbi, M.; Zampieri, N.; Eliseenkova, A.V.; Ornitz, D.M.; Goldfarb, M.; Mohammadi, M. Fibroblast growth factor (FGF) homologous factors share structural but not functional homology with FGFs. J. Biol. Chem. 2003, 278, 34226-34236. [CrossRef] [PubMed]

14. Schoorlemmer, J.; Goldfarb, M. Fibroblast growth factor homologous factors are intracellular signaling proteins. Curr. Biol. 2001, 11, 793-797. [CrossRef]

15. Yan, H.; Pablo, J.L.; Pitt, G.S. FGF14 regulates presynaptic Ca2+ channels and synaptic transmission. Cell Rep. 2013, 4, 66-75. [CrossRef] [PubMed]

16. Wu, Q.F.; Yang, L.; Li, S.; Wang, Q.; Yuan, X.B.; Gao, X.; Bao, L.; Zhang, X. Fibroblast growth factor 13 is a microtubule-stabilizing protein regulating neuronal polarization and migration. Cell 2012, 149, 1549-1564. [CrossRef]

17. Ornitz, D.M.; Xu, J.; Colvin, J.S.; McEwen, D.G.; MacArthur, C.A.; Coulier, F.; Gao, G.; Goldfarb, M. Receptor specificity of the fibroblast growth factor family. J. Biol. Chem. 1996, 271, 15292-15297. [CrossRef]

18. Givol, D.; Yayon, A. Complexity of FGF receptors: Genetic basis for structural diversity and functional specificity. FASEB J. 1992, 6, 3362-3369. [CrossRef]

19. Farrell, B.; Breeze, A.L. Structure, activation and dysregulation of fibroblast growth factor receptor kinases: Perspectives for clinical targeting. Biochem. Soc. Trans. 2018, 46, 1753-1770. [CrossRef]

20. Brown, A.; Robinson, C.J.; Gallagher, J.T.; Blundell, T.L. Cooperative heparin-mediated oligomerization of fibroblast growth factor-1 (FGF1) precedes recruitment of FGFR2 to ternary complexes. Biophys. J. 2013, 104, 1720-1730. [CrossRef] [PubMed]

21. Sarabipour, S.; Hristova, K. Mechanism of FGF receptor dimerization and activation. Nat. Commun. 2016, 7, 10262. [CrossRef] [PubMed]

22. Werner, S.; Duan, D.S.; de Vries, C.; Peters, K.G.; Johnson, D.E.; Williams, L.T. Differential splicing in the extracellular region of fibroblast growth factor receptor 1 generates receptor variants with different ligand-binding specificities. Mol. Cell Biol. 1992, 12, 82-88. [CrossRef] [PubMed]

23. Latko, M.; Czyrek, A.; Porebska, N.; Kucinska, M.; Otlewski, J.; Zakrzewska, M.; Opalinski, L. Cross-Talk between Fibroblast Growth Factor Receptors and Other Cell Surface Proteins. Cells 2019, 8, 455. [CrossRef] [PubMed] 
24. Zhang, J.; Tang, P.M.K.; Zhou, Y.; Cheng, A.S.L.; Yu, J.; Kang, W.; To, K.F. Targeting the Oncogenic FGF-FGFR Axis in Gastric Carcinogenesis. Cells 2019, 8, 637. [CrossRef]

25. Zhang, Y.; McKeehan, K.; Lin, Y.; Zhang, J.; Wang, F. Fibroblast growth factor receptor 1 (FGFR1) tyrosine phosphorylation regulates binding of FGFR substrate 2alpha (FRS2alpha) but not FRS2 to the receptor. Mol. Endocrinol. 2008, 22, 167-175. [CrossRef]

26. Goetz, R.; Mohammadi, M. Exploring mechanisms of FGF signalling through the lens of structural biology. Nat. Rev. Mol. Cell Biol. 2013, 14, 166-180. [CrossRef]

27. Dey, J.H.; Bianchi, F.; Voshol, J.; Bonenfant, D.; Oakeley, E.J.; Hynes, N.E. Targeting fibroblast growth factor receptors blocks PI3K/AKT signaling, induces apoptosis, and impairs mammary tumor outgrowth and metastasis. Cancer Res. 2010, 70, 4151-4162. [CrossRef]

28. Turner, N.; Grose, R. Fibroblast growth factor signalling: From development to cancer. Nat. Rev. Cancer 2010, 10, 116-129. [CrossRef]

29. Eswarakumar, V.P.; Lax, I.; Schlessinger, J. Cellular signaling by fibroblast growth factor receptors. Cytokine Growth Factor Rev. 2005, 16, 139-149. [CrossRef]

30. Tsang, M.; Dawid, I.B. Promotion and attenuation of FGF signaling through the Ras-MAPK pathway. Sci. STKE 2004, 2004 , pe17. [CrossRef]

31. Dionne, C.A.; Crumley, G.; Bellot, F.; Kaplow, J.M.; Searfoss, G.; Ruta, M.; Burgess, W.H.; Jaye, M.; Schlessinger, J. Cloning and expression of two distinct high-affinity receptors cross-reacting with acidic and basic fibroblast growth factors. EMBO J. 1990, 9 , 2685-2692. [CrossRef] [PubMed]

32. Madiai, F.; Hackshaw, K.V.; Chiu, I.M. Cloning and characterization of the mouse Fgf-1 gene. Gene 1996, 179, 231-236. [CrossRef]

33. Lea, R.; Papalopulu, N.; Amaya, E.; Dorey, K. Temporal and spatial expression of FGF ligands and receptors during Xenopus development. Dev. Dyn. 2009, 238, 1467-1479. [CrossRef]

34. Hebert, J.M.; Basilico, C.; Goldfarb, M.; Haub, O.; Martin, G.R. Isolation of cDNAs encoding four mouse FGF family members and characterization of their expression patterns during embryogenesis. Dev. Biol. 1990, 138, 454-463. [CrossRef]

35. Kimelman, D.; Kirschner, M. Synergistic induction of mesoderm by FGF and TGF-beta and the identification of an mRNA coding for FGF in the early Xenopus embryo. Cell 1987, 51, 869-877. [CrossRef]

36. Feldman, B.; Poueymirou, W.; Papaioannou, V.E.; DeChiara, T.M.; Goldfarb, M. Requirement of FGF-4 for postimplantation mouse development. Science 1995, 267, 246-249. [CrossRef]

37. Brookes, S.; Smith, R.; Thurlow, J.; Dickson, C.; Peters, G. The mouse homologue of hst/k-FGF: Sequence, genome organization and location relative to int-2. Nucleic Acids Res. 1989, 17, 4037-4045. [CrossRef]

38. Isaacs, H.V.; Tannahill, D.; Slack, J.M. Expression of a novel FGF in the Xenopus embryo. A new candidate inducing factor for mesoderm formation and anteroposterior specification. Development 1992, 114, 711-720. [CrossRef] [PubMed]

39. Zhan, X.; Bates, B.; Hu, X.G.; Goldfarb, M. The human FGF-5 oncogene encodes a novel protein related to fibroblast growth factors. Mol. Cell Biol. 1988, 8, 3487-3495. [CrossRef]

40. Ozawa, K.; Suzuki, S.; Asada, M.; Tomooka, Y.; Li, A.J.; Yoneda, A.; Komi, A.; Imamura, T. An alternatively spliced fibroblast growth factor (FGF)-5 mRNA is abundant in brain and translates into a partial agonist/antagonist for FGF-5 neurotrophic activity. J. Biol. Chem. 1998, 273, 29262-29271. [CrossRef]

41. Session, A.M.; Uno, Y.; Kwon, T.; Chapman, J.A.; Toyoda, A.; Takahashi, S.; Fukui, A.; Hikosaka, A.; Suzuki, A.; Kondo, M.; et al. Genome evolution in the allotetraploid frog Xenopus laevis. Nature 2016, 538, 336-343. [CrossRef]

42. Iida, S.; Yoshida, T.; Naito, K.; Sakamoto, H.; Katoh, O.; Hirohashi, S.; Sato, T.; Onda, M.; Sugimura, T.; Terada, M. Human hst-2 (FGF-6) oncogene: cDNA cloning and characterization. Oncogene 1992, 7, 303-309.

43. De Lapeyriere, O.; Rosnet, O.; Benharroch, D.; Raybaud, F.; Marchetto, S.; Planche, J.; Galland, F.; Mattei, M.G.; Copeland, N.G.; Jenkins, N.A.; et al. Structure, chromosome mapping and expression of the murine Fgf- 6 gene. Oncogene 1990, 5, 823-831. [PubMed]

44. Brookes, S.; Smith, R.; Casey, G.; Dickson, C.; Peters, G. Sequence organization of the human int-2 gene and its expression in teratocarcinoma cells. Oncogene 1989, 4, 429-436. [PubMed]

45. Dickson, C.; Acland, P.; Smith, R.; Dixon, M.; Deed, R.; MacAllan, D.; Walther, W.; Fuller-Pace, F.; Kiefer, P.; Peters, G. Characterization of int-2: A member of the fibroblast growth factor family. J. Cell Sci. Suppl. 1990, 13, 87-96. [CrossRef]

46. Kiefer, P.; Mathieu, M.; Close, M.J.; Peters, G.; Dickson, C. FGF3 from Xenopus laevis. EMBO J. 1993, 12, 4159-4168. [CrossRef]

47. Finch, P.W.; Rubin, J.S.; Miki, T.; Ron, D.; Aaronson, S.A. Human KGF is FGF-related with properties of a paracrine effector of epithelial cell growth. Science 1989, 245, 752-755. [CrossRef] [PubMed]

48. Mason, I.J.; Fuller-Pace, F.; Smith, R.; Dickson, C. FGF-7 (keratinocyte growth factor) expression during mouse development suggests roles in myogenesis, forebrain regionalisation and epithelial-mesenchymal interactions. Mech. Dev. 1994, 45, 15-30. [CrossRef]

49. Emoto, H.; Tagashira, S.; Mattei, M.G.; Yamasaki, M.; Hashimoto, G.; Katsumata, T.; Negoro, T.; Nakatsuka, M.; Birnbaum, D.; Coulier, F.; et al. Structure and expression of human fibroblast growth factor-10. J. Biol. Chem. 1997, 272, 23191-23194. [CrossRef] [PubMed]

50. Tagashira, S.; Harada, H.; Katsumata, T.; Itoh, N.; Nakatsuka, M. Cloning of mouse FGF10 and up-regulation of its gene expression during wound healing. Gene 1997, 197, 399-404. [CrossRef] 
51. Yokoyama, H.; Ide, H.; Tamura, K. FGF-10 stimulates limb regeneration ability in Xenopus laevis. Dev. Biol. 2001, 233, 72-79. [CrossRef] [PubMed]

52. Nakatake, Y.; Hoshikawa, M.; Asaki, T.; Kassai, Y.; Itoh, N. Identification of a novel fibroblast growth factor, FGF-22, preferentially expressed in the inner root sheath of the hair follicle. Biochim. Biophys. Acta 2001, 1517, 460-463. [CrossRef]

53. Tanaka, A.; Miyamoto, K.; Matsuo, H.; Matsumoto, K.; Yoshida, H. Human androgen-induced growth factor in prostate and breast cancer cells: Its molecular cloning and growth properties. FEBS Lett. 1995, 363, 226-230. [CrossRef]

54. Tanaka, A.; Miyamoto, K.; Minamino, N.; Takeda, M.; Sato, B.; Matsuo, H.; Matsumoto, K. Cloning and characterization of an androgen-induced growth factor essential for the androgen-dependent growth of mouse mammary carcinoma cells. Proc. Natl. Acad. Sci. USA 1992, 89, 8928-8932. [CrossRef]

55. Fletcher, R.B.; Baker, J.C.; Harland, R.M. FGF8 spliceforms mediate early mesoderm and posterior neural tissue formation in Xenopus. Development 2006, 133, 1703-1714. [CrossRef]

56. Hoshikawa, M.; Ohbayashi, N.; Yonamine, A.; Konishi, M.; Ozaki, K.; Fukui, S.; Itoh, N. Structure and expression of a novel fibroblast growth factor, FGF-17, preferentially expressed in the embryonic brain. Biochem. Biophys. Res. Commun. 1998, 244, 187-191. [CrossRef]

57. Hu, M.C.; Qiu, W.R.; Wang, Y.P.; Hill, D.; Ring, B.D.; Scully, S.; Bolon, B.; DeRose, M.; Luethy, R.; Simonet, W.S.; et al. FGF-18, a novel member of the fibroblast growth factor family, stimulates hepatic and intestinal proliferation. Mol. Cell Biol. 1998, 18, 6063-6074. [CrossRef]

58. Miyamoto, M.; Naruo, K.; Seko, C.; Matsumoto, S.; Kondo, T.; Kurokawa, T. Molecular cloning of a novel cytokine cDNA encoding the ninth member of the fibroblast growth factor family, which has a unique secretion property. Mol. Cell Biol. 1993, 13, 4251-4259. [CrossRef]

59. Santos-Ocampo, S.; Colvin, J.S.; Chellaiah, A.; Ornitz, D.M. Expression and biological activity of mouse fibroblast growth factor-9. J. Biol. Chem. 1996, 271, 1726-1731. [CrossRef]

60. Song, J.; Slack, J.M. XFGF-9: A new fibroblast growth factor from Xenopus embryos. Dev. Dyn. 1996, 206, 427-436. [CrossRef]

61. Miyake, A.; Konishi, M.; Martin, F.H.; Hernday, N.A.; Ozaki, K.; Yamamoto, S.; Mikami, T.; Arakawa, T.; Itoh, N. Structure and expression of a novel member, FGF-16, on the fibroblast growth factor family. Biochem. Biophys. Res. Commun. 1998, 243, 148-152. [CrossRef]

62. Sontag, D.P.; Cattini, P.A. Cloning and bacterial expression of postnatal mouse heart FGF-16. Mol. Cell Biochem. 2003, 242, 65-70. [CrossRef] [PubMed]

63. Kirikoshi, H.; Sagara, N.; Saitoh, T.; Tanaka, K.; Sekihara, H.; Shiokawa, K.; Katoh, M. Molecular cloning and characterization of human FGF-20 on chromosome 8p21.3-p22. Biochem. Biophys. Res. Commun. 2000, 274, 337-343. [CrossRef]

64. Hajihosseini, M.K.; Heath, J.K. Expression patterns of fibroblast growth factors-18 and -20 in mouse embryos is suggestive of novel roles in calvarial and limb development. Mech. Dev. 2002, 113, 79-83. [CrossRef]

65. Koga, C.; Adati, N.; Nakata, K.; Mikoshiba, K.; Furuhata, Y.; Sato, S.; Tei, H.; Sakaki, Y.; Kurokawa, T.; Shiokawa, K.; et al. Characterization of a novel member of the FGF family, XFGF-20, in Xenopus laevis. Biochem. Biophys. Res. Commun. 1999, 261, 756-765. [CrossRef]

66. Smallwood, P.M.; Munoz-Sanjuan, I.; Tong, P.; Macke, J.P.; Hendry, S.H.; Gilbert, D.J.; Copeland, N.G.; Jenkins, N.A.; Nathans, J. Fibroblast growth factor (FGF) homologous factors: New members of the FGF family implicated in nervous system development. Proc. Natl. Acad. Sci. USA 1996, 93, 9850-9857. [CrossRef]

67. Hartung, H.; Feldman, B.; Lovec, H.; Coulier, F.; Birnbaum, D.; Goldfarb, M. Murine FGF-12 and FGF-13: Expression in embryonic nervous system, connective tissue and heart. Mech. Dev. 1997, 64, 31-39. [CrossRef]

68. Fukui, L.; Henry, J.J. FGF signaling is required for lens regeneration in Xenopus laevis. Biol. Bull. 2011, 221, 137-145. [CrossRef]

69. Gecz, J.; Baker, E.; Donnelly, A.; Ming, J.E.; McDonald-McGinn, D.M.; Spinner, N.B.; Zackai, E.H.; Sutherland, G.R.; Mulley, J.C. Fibroblast growth factor homologous factor 2 (FHF2): Gene structure, expression and mapping to the Borjeson-ForssmanLehmann syndrome region in Xq26 delineated by a duplication breakpoint in a BFLS-like patient. Hum. Genet. 1999, 104, 56-63. [CrossRef]

70. Nishimoto, S.; Nishida, E. Fibroblast growth factor 13 is essential for neural differentiation in Xenopus early embryonic development. J. Biol. Chem. 2007, 282, 24255-24261. [CrossRef]

71. Goetz, R.; Dover, K.; Laezza, F.; Shtraizent, N.; Huang, X.; Tchetchik, D.; Eliseenkova, A.V.; Xu, C.F.; Neubert, T.A.; Ornitz, D.M.; et al. Crystal structure of a fibroblast growth factor homologous factor (FHF) defines a conserved surface on FHFs for binding and modulation of voltage-gated sodium channels. J. Biol. Chem. 2009, 284, 17883-17896. [CrossRef]

72. Yamamoto, S.; Mikami, T.; Konishi, M.; Itoh, N. Stage-specific expression of a novel isoform of mouse FGF-14 (FHF-4) in spermatocytes. Biochim. Biophys. Acta 2000, 1490, 121-124. [CrossRef]

73. Vergnes, L.; Lee, J.M.; Chin, R.G.; Auwerx, J.; Reue, K. Diet1 functions in the FGF15/19 enterohepatic signaling axis to modulate bile acid and lipid levels. Cell Metab. 2013, 17, 916-928. [CrossRef]

74. Nishimura, T.; Utsunomiya, Y.; Hoshikawa, M.; Ohuchi, H.; Itoh, N. Structure and expression of a novel human FGF, FGF-19, expressed in the fetal brain. Biochim. Biophys. Acta 1999, 1444, 148-151. [CrossRef]

75. Nishimura, T.; Nakatake, Y.; Konishi, M.; Itoh, N. Identification of a novel FGF, FGF-21, preferentially expressed in the liver. Biochim. Biophys. Acta 2000, 1492, 203-206. [CrossRef] 
76. Yamashita, T.; Yoshioka, M.; Itoh, N. Identification of a novel fibroblast growth factor, FGF-23, preferentially expressed in the ventrolateral thalamic nucleus of the brain. Biochem. Biophys. Res. Commun. 2000, 277, 494-498. [CrossRef]

77. Reid, H.H.; Wilks, A.F.; Bernard, O. Two forms of the basic fibroblast growth factor receptor-like mRNA are expressed in the developing mouse brain. Proc. Natl. Acad. Sci. USA 1990, 87, 1596-1600. [CrossRef]

78. Friesel, R.; Dawid, I.B. cDNA cloning and developmental expression of fibroblast growth factor receptors from Xenopus laevis. Mol. Cell Biol. 1991, 11, 2481-2488. [CrossRef]

79. Zhang, Y.; Gorry, M.C.; Post, J.C.; Ehrlich, G.D. Genomic organization of the human fibroblast growth factor receptor 2 (FGFR2) gene and comparative analysis of the human FGFR gene family. Gene 1999, 230, 69-79. [CrossRef]

80. Orr-Urtreger, A.; Bedford, M.T.; Burakova, T.; Arman, E.; Zimmer, Y.; Yayon, A.; Givol, D.; Lonai, P. Developmental localization of the splicing alternatives of fibroblast growth factor receptor-2 (FGFR2). Dev. Biol. 1993, 158, 475-486. [CrossRef] [PubMed]

81. Friesel, R.; Brown, S.A. Spatially restricted expression of fibroblast growth factor receptor-2 during Xenopus development. Development 1992, 116, 1051-1058. [CrossRef] [PubMed]

82. Keegan, K.; Johnson, D.E.; Williams, L.T.; Hayman, M.J. Isolation of an additional member of the fibroblast growth factor receptor family, FGFR-3. Proc. Natl. Acad. Sci. USA 1991, 88, 1095-1099. [CrossRef] [PubMed]

83. Chellaiah, A.T.; McEwen, D.G.; Werner, S.; Xu, J.; Ornitz, D.M. Fibroblast growth factor receptor (FGFR) 3. Alternative splicing in immunoglobulin-like domain III creates a receptor highly specific for acidic FGF/FGF-1. J. Biol. Chem. 1994, 269 , 11620-11627. [CrossRef]

84. Hongo, I.; Kengaku, M.; Okamoto, H. FGF signaling and the anterior neural induction in Xenopus. Dev. Biol. 1999, 216, 561-581. [CrossRef]

85. Partanen, J.; Makela, T.P.; Eerola, E.; Korhonen, J.; Hirvonen, H.; Claesson-Welsh, L.; Alitalo, K. FGFR-4, a novel acidic fibroblast growth factor receptor with a distinct expression pattern. EMBO J. 1991, 10, 1347-1354. [CrossRef]

86. Stark, K.L.; McMahon, J.A.; McMahon, A.P. FGFR-4, a new member of the fibroblast growth factor receptor family, expressed in the definitive endoderm and skeletal muscle lineages of the mouse. Development 1991, 113, 641-651. [CrossRef]

87. Riou, J.F.; Clavilier, L.; Boucaut, J.C. Early regionalized expression of a novel Xenopus fibroblast growth factor receptor in neuroepithelium. Biochem. Biophys. Res. Commun. 1996, 218, 198-204. [CrossRef] [PubMed]

88. Zhang, J.; Houston, D.W.; King, M.L.; Payne, C.; Wylie, C.; Heasman, J. The role of maternal VegT in establishing the primary germ layers in Xenopus embryos. Cell 1998, 94, 515-524. [CrossRef]

89. Joseph, E.M.; Melton, D.A. Mutant Vg1 ligands disrupt endoderm and mesoderm formation in Xenopus embryos. Development 1998, 125, 2677-2685. [CrossRef]

90. Kofron, M.; Demel, T.; Xanthos, J.; Lohr, J.; Sun, B.; Sive, H.; Osada, S.; Wright, C.; Wylie, C.; Heasman, J. Mesoderm induction in Xenopus is a zygotic event regulated by maternal VegT via TGFbeta growth factors. Development 1999, 126, 5759-5770. [CrossRef]

91. Cha, S.W.; Hwang, Y.S.; Chae, J.P.; Lee, S.Y.; Lee, H.S.; Daar, I.; Park, M.J.; Kim, J. Inhibition of FGF signaling causes expansion of the endoderm in Xenopus. Biochem. Biophys. Res. Commun. 2004, 315, 100-106. [CrossRef]

92. Umair, Z.; Kumar, S.; Rafiq, K.; Kumar, V.; Reman, Z.U.; Lee, S.H.; Kim, S.; Lee, J.Y.; Lee, U.; Kim, J. Dusp1 modulates activin/smad2 mediated germ layer specification via FGF signal inhibition in Xenopus embryos. Anim. Cells Syst. 2020, 24, 359-370. [CrossRef]

93. Brown, J.L.; Snir, M.; Noushmehr, H.; Kirby, M.; Hong, S.K.; Elkahloun, A.G.; Feldman, B. Transcriptional profiling of endogenous germ layer precursor cells identifies dusp4 as an essential gene in zebrafish endoderm specification. Proc. Natl. Acad. Sci. USA 2008, 105, 12337-12342. [CrossRef]

94. Poulain, M.; Furthauer, M.; Thisse, B.; Thisse, C.; Lepage, T. Zebrafish endoderm formation is regulated by combinatorial Nodal, FGF and BMP signalling. Development 2006, 133, 2189-2200. [CrossRef]

95. Sui, L.; Mfopou, J.K.; Geens, M.; Sermon, K.; Bouwens, L. FGF signaling via MAPK is required early and improves Activin A-induced definitive endoderm formation from human embryonic stem cells. Biochem. Biophys. Res. Commun. 2012, 426, 380-385. [CrossRef]

96. Paraiso, K.D.; Cho, J.S.; Yong, J.; Cho, K.W.Y. Early Xenopus gene regulatory programs, chromatin states, and the role of maternal transcription factors. Curr. Top. Dev. Biol. 2020, 139, 35-60. [CrossRef]

97. Nieuwkoop, P.D. The formation of the mesoderm in urodelean amphibians: I. Induction by the endoderm. Wilhelm Roux Arch. Entwickl Mech. Org. 1969, 162, 341-373. [CrossRef]

98. Slack, J.M.; Darlington, B.G.; Heath, J.K.; Godsave, S.F. Mesoderm induction in early Xenopus embryos by heparin-binding growth factors. Nature 1987, 326, 197-200. [CrossRef] [PubMed]

99. Dvorak, P.; Flechon, J.E.; Thompson, E.M.; Horak, V.; Adenot, P.; Renard, J.P. Embryoglycans regulate FGF-2-mediated mesoderm induction in the rabbit embryo. J. Cell Sci. 1997, 110 Pt 1, 1-10. [CrossRef]

100. Burdsal, C.A.; Flannery, M.L.; Pedersen, R.A. FGF-2 alters the fate of mouse epiblast from ectoderm to mesoderm in vitro. Dev. Biol. 1998, 198, 231-244. [CrossRef]

101. Amaya, E.; Musci, T.J.; Kirschner, M.W. Expression of a dominant negative mutant of the FGF receptor disrupts mesoderm formation in Xenopus embryos. Cell 1991, 66, 257-270. [CrossRef]

102. Yamaguchi, T.P.; Harpal, K.; Henkemeyer, M.; Rossant, J. fgfr-1 is required for embryonic growth and mesodermal patterning during mouse gastrulation. Genes Dev. 1994, 8, 3032-3044. [CrossRef] [PubMed] 
103. LaBonne, C.; Whitman, M. Mesoderm induction by activin requires FGF-mediated intracellular signals. Development 1994, 120, 463-472. [CrossRef] [PubMed]

104. Amaya, E.; Stein, P.A.; Musci, T.J.; Kirschner, M.W. FGF signalling in the early specification of mesoderm in Xenopus. Development 1993, 118, 477-487. [CrossRef] [PubMed]

105. Dawid, I.B.; Taira, M.; Good, P.J.; Rebagliati, M.R. The role of growth factors in embryonic induction in Xenopus laevis. Mol. Reprod. Dev. 1992, 32, 136-144. [CrossRef] [PubMed]

106. Takenaga, M.; Fukumoto, M.; Hori, Y. Regulated Nodal signaling promotes differentiation of the definitive endoderm and mesoderm from ES cells. J. Cell Sci. 2007, 120, 2078-2090. [CrossRef]

107. Agius, E.; Oelgeschlager, M.; Wessely, O.; Kemp, C.; de Robertis, E.M. Endodermal Nodal-related signals and mesoderm induction in Xenopus. Development 2000, 127, 1173-1183. [CrossRef] [PubMed]

108. Feldman, B.; Gates, M.A.; Egan, E.S.; Dougan, S.T.; Rennebeck, G.; Sirotkin, H.I.; Schier, A.F.; Talbot, W.S. Zebrafish organizer development and germ-layer formation require nodal-related signals. Nature 1998, 395, 181-185. [CrossRef]

109. Jones, C.M.; Kuehn, M.R.; Hogan, B.L.; Smith, J.C.; Wright, C.V. Nodal-related signals induce axial mesoderm and dorsalize mesoderm during gastrulation. Development 1995, 121, 3651-3662. [CrossRef]

110. Kumar, V.; Umair, Z.; Kumar, S.; Lee, U.; Kim, J. Smad2 and Smad3 differentially modulate chordin transcription via direct binding on the distal elements in gastrula Xenopus embryos. Biochem. Biophys. Res. Commun. 2021, 559, 168-175. [CrossRef]

111. Cornell, R.A.; Musci, T.J.; Kimelman, D. FGF is a prospective competence factor for early activin-type signals in Xenopus mesoderm induction. Development 1995, 121, 2429-2437. [CrossRef]

112. Tannahill, D.; Isaacs, H.V.; Close, M.J.; Peters, G.; Slack, J.M. Developmental expression of the Xenopus int-2 (FGF-3) gene: Activation by mesodermal and neural induction. Development 1992, 115, 695-702. [CrossRef]

113. Branney, P.A.; Faas, L.; Steane, S.E.; Pownall, M.E.; Isaacs, H.V. Characterisation of the fibroblast growth factor dependent transcriptome in early development. PLoS ONE 2009, 4, e4951. [CrossRef]

114. Fletcher, R.B.; Harland, R.M. The role of FGF signaling in the establishment and maintenance of mesodermal gene expression in Xenopus. Dev. Dyn. 2008, 237, 1243-1254. [CrossRef]

115. Christen, B.; Slack, J.M. FGF-8 is associated with anteroposterior patterning and limb regeneration in Xenopus. Dev. Biol. 1997, 192, 455-466. [CrossRef]

116. Isaacs, H.V. New perspectives on the role of the fibroblast growth factor family in amphibian development. Cell Mol. Life Sci. 1997, 53, 350-361. [CrossRef]

117. Conlon, F.L.; Sedgwick, S.G.; Weston, K.M.; Smith, J.C. Inhibition of Xbra transcription activation causes defects in mesodermal patterning and reveals autoregulation of Xbra in dorsal mesoderm. Development 1996, 122, 2427-2435. [CrossRef] [PubMed]

118. Schulte-Merker, S.; Smith, J.C. Mesoderm formation in response to Brachyury requires FGF signalling. Curr. Biol. 1995, 5, 62-67. [CrossRef]

119. Ryan, K.; Garrett, N.; Mitchell, A.; Gurdon, J.B. Eomesodermin, a key early gene in Xenopus mesoderm differentiation. Cell 1996, 87, 989-1000. [CrossRef]

120. Kumar, S.; Umair, Z.; Yoon, J.; Lee, U.; Kim, S.C.; Park, J.B.; Lee, J.Y.; Kim, J. Xbra and Smad-1 cooperate to activate the transcription of neural repressor ventx1.1 in Xenopus embryos. Sci. Rep. 2018, 8, 11391. [CrossRef]

121. Brewster, R.; Mullor, J.L.; Ruiz i Altaba, A. Gli2 functions in FGF signaling during antero-posterior patterning. Development 2000, 127, 4395-4405. [CrossRef]

122. Kim, J.; Lin, J.J.; Xu, R.H.; Kung, H.F. Mesoderm induction by heterodimeric AP-1 (c-Jun and c-Fos) and its involvement in mesoderm formation through the embryonic fibroblast growth factor/Xbra autocatalytic loop during the early development of Xenopus embryos. J. Biol. Chem. 1998, 273, 1542-1550. [CrossRef]

123. Yoon, J.; Kim, J.H.; Lee, S.Y.; Kim, S.; Park, J.B.; Lee, J.Y.; Kim, J. PV. 1 induced by FGF-Xbra functions as a repressor of neurogenesis in Xenopus embryos. BMB Rep. 2014, 47, 673-678. [CrossRef]

124. Rao, Y. Conversion of a mesodermalizing molecule, the Xenopus Brachyury gene, into a neuralizing factor. Genes Dev. 1994, 8 , 939-947. [CrossRef] [PubMed]

125. Isaacs, H.V.; Pownall, M.E.; Slack, J.M. eFGF regulates Xbra expression during Xenopus gastrulation. EMBO J. 1994, $13,4469-4481$. [CrossRef]

126. Kuroda, H.; Wessely, O.; de Robertis, E.M. Neural induction in Xenopus: Requirement for ectodermal and endomesodermal signals via Chordin, Noggin, beta-Catenin, and Cerberus. PLoS Biol. 2004, 2, E92. [CrossRef]

127. Delaune, E.; Lemaire, P.; Kodjabachian, L. Neural induction in Xenopus requires early FGF signalling in addition to BMP inhibition. Development 2005, 132, 299-310. [CrossRef] [PubMed]

128. Mitchell, T.S.; Sheets, M.D. The FGFR pathway is required for the trunk-inducing functions of Spemann's organizer. Dev. Biol. 2001, 237, 295-305. [CrossRef] [PubMed]

129. Shiotsugu, J.; Katsuyama, Y.; Arima, K.; Baxter, A.; Koide, T.; Song, J.; Chandraratna, R.A.; Blumberg, B. Multiple points of interaction between retinoic acid and FGF signaling during embryonic axis formation. Development 2004, 131, 2653-2667. [CrossRef]

130. Kumar, S.; Umair, Z.; Kumar, V.; Lee, U.; Choi, S.C.; Kim, J. Ventx1.1 competes with a transcriptional activator Xcad2 to regulate negatively its own expression. BMB Rep. 2019, 52, 403-408. [CrossRef] 
131. Keenan, I.D.; Sharrard, R.M.; Isaacs, H.V. FGF signal transduction and the regulation of Cdx gene expression. Dev. Biol. 2006, 299, 478-488. [CrossRef] [PubMed]

132. Levy, V.; Marom, K.; Zins, S.; Koutsia, N.; Yelin, R.; Fainsod, A. The competence of marginal zone cells to become Spemann's organizer is controlled by Xcad2. Dev. Biol. 2002, 248, 40-51. [CrossRef] [PubMed]

133. Kolpakova, A.; Katz, S.; Keren, A.; Rojtblat, A.; Bengal, E. Transcriptional regulation of mesoderm genes by MEF2D during early Xenopus development. PLoS ONE 2013, 8, e69693. [CrossRef] [PubMed]

134. Nentwich, O.; Dingwell, K.S.; Nordheim, A.; Smith, J.C. Downstream of FGF during mesoderm formation in Xenopus: The roles of Elk-1 and Egr-1. Dev. Biol. 2009, 336, 313-326. [CrossRef]

135. Reichert, S.; Randall, R.A.; Hill, C.S. A BMP regulatory network controls ectodermal cell fate decisions at the neural plate border. Development 2013, 140, 4435-4444. [CrossRef]

136. Lee, H.S.; Lee, S.Y.; Lee, H.; Hwang, Y.S.; Cha, S.W.; Park, S.; Lee, J.Y.; Park, J.B.; Kim, S.; Park, M.J.; et al. Direct response elements of BMP within the PV.1A promoter are essential for its transcriptional regulation during early Xenopus development. PLoS ONE 2011, 6, e22621. [CrossRef]

137. Umair, Z.; Kumar, S.; Kim, D.H.; Rafiq, K.; Kumar, V.; Kim, S.; Park, J.B.; Lee, J.Y.; Lee, U.; Kim, J. Ventx1.1 as a Direct Repressor of Early Neural Gene zic3 in Xenopus laevis. Mol. Cells 2018, 41, 1061-1071. [CrossRef]

138. Ault, K.T.; Dirksen, M.L.; Jamrich, M. A novel homeobox gene PV.1 mediates induction of ventral mesoderm in Xenopus embryos. Proc. Natl. Acad. Sci. USA 1996, 93, 6415-6420. [CrossRef]

139. Marchal, L.; Luxardi, G.; Thome, V.; Kodjabachian, L. BMP inhibition initiates neural induction via FGF signaling and Zic genes. Proc. Natl. Acad. Sci. USA 2009, 106, 17437-17442. [CrossRef]

140. Furthauer, M.; van Celst, J.; Thisse, C.; Thisse, B. Fgf signalling controls the dorsoventral patterning of the zebrafish embryo. Development 2004, 131, 2853-2864. [CrossRef]

141. Smith, J.C.; Slack, J.M. Dorsalization and neural induction: Properties of the organizer in Xenopus laevis. J. Embryol. Exp. Morphol. 1983, 78, 299-317.

142. Leikola, A. Hensen's node-the 'organizer' of the amniote embryo. Experientia 1976, 32, 269-277. [CrossRef]

143. Shih, J.; Fraser, S.E. Characterizing the zebrafish organizer: Microsurgical analysis at the early-shield stage. Development 1996, 122, 1313-1322. [CrossRef]

144. Smith, W.C.; Harland, R.M. Expression cloning of noggin, a new dorsalizing factor localized to the Spemann organizer in Xenopus embryos. Cell 1992, 70, 829-840. [CrossRef]

145. Sasal, Y.; Lu, B.; Steinbelsser, H.; de Robertis, E.M. Regulation of neural induction by the Chd and Bmp-4 antagonistic patterning signals in Xenopus. Nature 1995, 378, 419. [CrossRef] [PubMed]

146. Lemaire, P.; Kodjabachian, L. The vertebrate organizer: Structure and molecules. Trends Genet. 1996, 12, 525-531. [CrossRef]

147. Stern, C.D. Neural induction: 10 years on since the 'default model'. Curr. Opin. Cell Biol. 2006, 18, 692-697. [CrossRef]

148. Khokha, M.K.; Yeh, J.; Grammer, T.C.; Harland, R.M. Depletion of three BMP antagonists from Spemann's organizer leads to a catastrophic loss of dorsal structures. Dev. Cell 2005, 8, 401-411. [CrossRef]

149. Linker, C.; Stern, C.D. Neural induction requires BMP inhibition only as a late step, and involves signals other than FGF and Wnt antagonists. Development 2004, 131, 5671-5681. [CrossRef]

150. Stern, C.D. Neural induction: Old problem, new findings, yet more questions. Development 2005, 132, 2007-2021. [CrossRef] [PubMed]

151. Sasai, Y.; Lu, B.; Piccolo, S.; de Robertis, E.M. Endoderm induction by the organizer-secreted factors chordin and noggin in Xenopus animal caps. EMBO J. 1996, 15, 4547-4555. [CrossRef] [PubMed]

152. Launay, C.; Fromentoux, V.; Shi, D.L.; Boucaut, J.C. A truncated FGF receptor blocks neural induction by endogenous Xenopus inducers. Development 1996, 122, 869-880. [CrossRef]

153. Kumar, S.; Umair, Z.; Kumar, V.; Kumar, S.; Lee, U.; Kim, J. Foxd411.1 negatively regulates transcription of neural repressor ventx1.1 during neuroectoderm formation in Xenopus embryos. Sci. Rep. 2020, 10, 16780. [CrossRef]

154. Hardcastle, Z.; Chalmers, A.D.; Papalopulu, N. FGF-8 stimulates neuronal differentiation through FGFR-4a and interferes with mesoderm induction in Xenopus embryos. Curr. Biol. 2000, 10, 1511-1514. [CrossRef]

155. Kang, W.; Hebert, J.M. FGF Signaling is Necessary for Neurogenesis in Young Mice and Sufficient to Reverse Its Decline in Old Mice. J. Neurosci. 2015, 35, 10217-10223. [CrossRef]

156. Streit, A.; Berliner, A.J.; Papanayotou, C.; Sirulnik, A.; Stern, C.D. Initiation of neural induction by FGF signalling before gastrulation. Nature 2000, 406, 74-78. [CrossRef]

157. Crossley, P.H.; Martinez, S.; Martin, G.R. Midbrain development induced by FGF8 in the chick embryo. Nature 1996, $380,66-68$. [CrossRef]

158. Da Silva, S.; Cepko, C.L. Fgf8 Expression and Degradation of Retinoic Acid are Required for Patterning a High-Acuity Area in the Retina. Dev. Cell 2017, 42, 68-81.e66. [CrossRef]

159. Rogers, C.D.; Moody, S.A.; Casey, E.S. Neural induction and factors that stabilize a neural fate. Birth Defects Res. C Embryo Today 2009, 87, 249-262. [CrossRef]

160. Pera, E.M.; Ikeda, A.; Eivers, E.; de Robertis, E.M. Integration of IGF, FGF, and anti-BMP signals via Smad1 phosphorylation in neural induction. Genes Dev. 2003, 17, 3023-3028. [CrossRef] 
161. Suzuki, A.; Thies, R.S.; Yamaji, N.; Song, J.J.; Wozney, J.M.; Murakami, K.; Ueno, N. A truncated bone morphogenetic protein receptor affects dorsal-ventral patterning in the early Xenopus embryo. Proc. Natl. Acad. Sci. USA 1994, 91, 10255-10259. [CrossRef]

162. Hwang, Y.S.; Seo, J.J.; Cha, S.W.; Lee, H.S.; Lee, S.Y.; Roh, D.H.; Kung Hf, H.F.; Kim, J.; Ja Park, M. Antimorphic PV.1 causes secondary axis by inducing ectopic organizer. Biochem. Biophys. Res. Commun. 2002, 292, 1081-1086. [CrossRef]

163. Kumano, G.; Ezal, C.; Smith, W.C. Boundaries and functional domains in the animal/vegetal axis of Xenopus gastrula mesoderm. Dev. Biol. 2001, 236, 465-477. [CrossRef]

164. Curran, K.L.; Grainger, R.M. Expression of activated MAP kinase in Xenopus laevis embryos: Evaluating the roles of FGF and other signaling pathways in early induction and patterning. Dev. Biol. 2000, 228, 41-56. [CrossRef]

165. Christen, B.; Slack, J.M. Spatial response to fibroblast growth factor signalling in Xenopus embryos. Development 1999, 126 , 119-125. [CrossRef]

166. De Robertis, E.M.; Kuroda, H. Dorsal-ventral patterning and neural induction in Xenopus embryos. Annu Rev. Cell Dev. Biol. 2004, 20, 285-308. [CrossRef]

167. Munoz-Sanjuan, I.; Brivanlou, A.H. Neural induction, the default model and embryonic stem cells. Nat. Rev. NeuroSci. 2002, 3, 271-280. [CrossRef]

168. Cox, W.G.; Hemmati-Brivanlou, A. Caudalization of neural fate by tissue recombination and bFGF. Development 1995, 121, 4349-4358. [CrossRef] [PubMed]

169. Lamb, T.M.; Harland, R.M. Fibroblast growth factor is a direct neural inducer, which combined with noggin generates anteriorposterior neural pattern. Development 1995, 121, 3627-3636. [CrossRef] [PubMed]

170. Ribisi, S., Jr.; Mariani, F.V.; Aamar, E.; Lamb, T.M.; Frank, D.; Harland, R.M. Ras-mediated FGF signaling is required for the formation of posterior but not anterior neural tissue in Xenopus laevis. Dev. Biol. 2000, 227, 183-196. [CrossRef] [PubMed]

171. Pownall, M.E.; Tucker, A.S.; Slack, J.M.; Isaacs, H.V. eFGF, Xcad3 and Hox genes form a molecular pathway that establishes the anteroposterior axis in Xenopus. Development 1996, 122, 3881-3892. [CrossRef] [PubMed]

172. Sunmonu, N.A.; Li, K.; Li, J.Y. Numerous isoforms of Fgf8 reflect its multiple roles in the developing brain. J. Cell Physiol. 2011, 226, 1722-1726. [CrossRef]

173. Shim, S.; Bae, N.; Park, S.Y.; Kim, W.S.; Han, J.K. Isolation of Xenopus FGF-8b and comparison with FGF-8a. Mol. Cells 2005, 19, 310-317. [PubMed]

174. Liu, A.; Losos, K.; Joyner, A.L. FGF8 can activate Gbx2 and transform regions of the rostral mouse brain into a hindbrain fate. Development 1999, 126, 4827-4838. [CrossRef] [PubMed]

175. Lee, S.M.; Danielian, P.S.; Fritzsch, B.; McMahon, A.P. Evidence that FGF8 signalling from the midbrain-hindbrain junction regulates growth and polarity in the developing midbrain. Development 1997, 124, 959-969. [CrossRef]

176. Martin, B.L.; Kimelman, D. Wnt signaling and the evolution of embryonic posterior development. Curr. Biol. 2009, 19, R215-R219. [CrossRef]

177. Epstein, M.; Pillemer, G.; Yelin, R.; Yisraeli, J.K.; Fainsod, A. Patterning of the embryo along the anterior-posterior axis: The role of the caudal genes. Development 1997, 124, 3805-3814. [CrossRef]

178. Marom, K.; Shapira, E.; Fainsod, A. The chicken caudal genes establish an anterior-posterior gradient by partially overlapping temporal and spatial patterns of expression. Mech. Dev. 1997, 64, 41-52. [CrossRef]

179. Bayha, E.; Jorgensen, M.C.; Serup, P.; Grapin-Botton, A. Retinoic acid signaling organizes endodermal organ specification along the entire antero-posterior axis. PLoS ONE 2009, 4, e5845. [CrossRef]

180. Kiecker, C.; Niehrs, C. A morphogen gradient of Wnt/beta-catenin signalling regulates anteroposterior neural patterning in Xenopus. Development 2001, 128, 4189-4201. [CrossRef]

181. Ikeya, M.; Takada, S. Wnt-3a is required for somite specification along the anteroposterior axis of the mouse embryo and for regulation of cdx-1 expression. Mech. Dev. 2001, 103, 27-33. [CrossRef]

182. Doniach, T. Basic FGF as an inducer of anteroposterior neural pattern. Cell 1995, 83, 1067-1070. [CrossRef]

183. Fisher, M.E.; Isaacs, H.V.; Pownall, M.E. eFGF is required for activation of XmyoD expression in the myogenic cell lineage of Xenopus laevis. Development 2002, 129, 1307-1315. [CrossRef]

184. Hoppler, S.; Brown, J.D.; Moon, R.T. Expression of a dominant-negative Wnt blocks induction of MyoD in Xenopus embryos. Genes Dev. 1996, 10, 2805-2817. [CrossRef]

185. Bel-Vialar, S.; Itasaki, N.; Krumlauf, R. Initiating Hox gene expression: In the early chick neural tube differential sensitivity to FGF and RA signaling subdivides the HoxB genes in two distinct groups. Development 2002, 129, 5103-5115. [CrossRef]

186. Wilson, V.; Olivera-Martinez, I.; Storey, K.G. Stem cells, signals and vertebrate body axis extension. Development 2009, 136, 1591-1604. [CrossRef]

187. Diez del Corral, R.; Storey, K.G. Opposing FGF and retinoid pathways: A signalling switch that controls differentiation and patterning onset in the extending vertebrate body axis. Bioessays 2004, 26, 857-869. [CrossRef]

188. Shiratori, H.; Hamada, H. The left-right axis in the mouse: From origin to morphology. Development 2006, 133, 2095-2104. [CrossRef] [PubMed]

189. Fischer, A.; Viebahn, C.; Blum, M. FGF8 acts as a right determinant during establishment of the left-right axis in the rabbit. Curr. Biol. 2002, 12, 1807-1816. [CrossRef] 
190. Meyers, E.N.; Martin, G.R. Differences in left-right axis pathways in mouse and chick: Functions of FGF8 and SHH. Science 1999, 285, 403-406. [CrossRef] [PubMed]

191. Levin, M.; Johnson, R.L.; Stern, C.D.; Kuehn, M.; Tabin, C. A molecular pathway determining left-right asymmetry in chick embryogenesis. Cell 1995, 82, 803-814. [CrossRef]

192. Okada, Y.; Takeda, S.; Tanaka, Y.; Belmonte, J.I.; Hirokawa, N. Mechanism of nodal flow: A conserved symmetry breaking event in left-right axis determination. Cell 2005, 121, 633-644. [CrossRef] [PubMed]

193. Albertson, R.C.; Yelick, P.C. Roles for fgf8 signaling in left-right patterning of the visceral organs and craniofacial skeleton. Dev. Biol. 2005, 283, 310-321. [CrossRef] [PubMed]

194. Tanaka, Y.; Okada, Y.; Hirokawa, N. FGF-induced vesicular release of Sonic hedgehog and retinoic acid in leftward nodal flow is critical for left-right determination. Nature 2005, 435, 172-177. [CrossRef] [PubMed]

195. Neugebauer, J.M.; Amack, J.D.; Peterson, A.G.; Bisgrove, B.W.; Yost, H.J. FGF signalling during embryo development regulates cilia length in diverse epithelia. Nature 2009, 458, 651-654. [CrossRef]

196. Hong, S.K.; Dawid, I.B. FGF-dependent left-right asymmetry patterning in zebrafish is mediated by Ier2 and Fibp1. Proc. Natl. Acad. Sci. USA 2009, 106, 2230-2235. [CrossRef]

197. Eblaghie, M.C.; Lunn, J.S.; Dickinson, R.J.; Munsterberg, A.E.; Sanz-Ezquerro, J.J.; Farrell, E.R.; Mathers, J.; Keyse, S.M.; Storey, K.; Tickle, C. Negative feedback regulation of FGF signaling levels by Pyst1/MKP3 in chick embryos. Curr. Biol. 2003, 13, $1009-1018$. [CrossRef]

198. Casci, T.; Vinos, J.; Freeman, M. Sprouty, an intracellular inhibitor of Ras signaling. Cell 1999, 96, 655-665. [CrossRef]

199. Kovalenko, D.; Yang, X.; Nadeau, R.J.; Harkins, L.K.; Friesel, R. Sef inhibits fibroblast growth factor signaling by inhibiting FGFR1 tyrosine phosphorylation and subsequent ERK activation. J. Biol. Chem. 2003, 278, 14087-14091. [CrossRef]

200. Sivak, J.M.; Petersen, L.F.; Amaya, E. FGF signal interpretation is directed by Sprouty and Spred proteins during mesoderm formation. Dev. Cell 2005, 8, 689-701. [CrossRef]

201. Lax, I.; Wong, A.; Lamothe, B.; Lee, A.; Frost, A.; Hawes, J.; Schlessinger, J. The docking protein FRS2alpha controls a MAP kinase-mediated negative feedback mechanism for signaling by FGF receptors. Mol. Cell 2002, 10, 709-719. [CrossRef]

202. Fico, A.; Maina, F.; Dono, R. Fine-tuning of cell signaling by glypicans. Cell Mol. Life Sci. 2011, 68, 923-929. [CrossRef] [PubMed]

203. Garcia-Garcia, M.J.; Anderson, K.V. Essential role of glycosaminoglycans in Fgf signaling during mouse gastrulation. Cell 2003, 114, 727-737. [CrossRef]

204. Galli, A.; Roure, A.; Zeller, R.; Dono, R. Glypican 4 modulates FGF signalling and regulates dorsoventral forebrain patterning in Xenopus embryos. Development 2003, 130, 4919-4929. [CrossRef]

205. Korsensky, L.; Ron, D. Regulation of FGF signaling: Recent insights from studying positive and negative modulators. Semin. Cell Dev. Biol. 2016, 53, 101-114. [CrossRef] [PubMed]

206. Saydmohammed, M.; Vollmer, L.L.; Onuoha, E.O.; Vogt, A.; Tsang, M. A high-content screening assay in transgenic zebrafish identifies two novel activators of fgf signaling. Birth Defects Res. C Embryo Today 2011, 93, 281-287. [CrossRef] [PubMed]

207. Jaeger, I.; Arber, C.; Risner-Janiczek, J.R.; Kuechler, J.; Pritzsche, D.; Chen, I.C.; Naveenan, T.; Ungless, M.A.; Li, M. Temporally controlled modulation of FGF/ERK signaling directs midbrain dopaminergic neural progenitor fate in mouse and human pluripotent stem cells. Development 2011, 138, 4363-4374. [CrossRef] 